\title{
PRAVNE POSLJEDICE NEVALJANOSTI TRAJNOGA UGOVORA
}

Dr. sc. Ivan Tot*

\author{
UDK 347.44(497.5) \\ https://doi.org/10.30925/zpfsr.40.2.2 \\ Ur.: 5. veljače 2019 . \\ Pr.: 20. lipnja 2019. \\ Izvorni znanstveni rad
}

\begin{abstract}
Sažetak
Nevaljanost ugovora u hrvatskom pravu, kao i u švicarskom, austrijskom $i$ njemačkom pravu, načelno proizvodi ex tunc učinak. Jedna od pravnih posljedica nevaljanosti ugovora je i obveza restitucije koja nastaje ako je neka strana izvršila drugoj činidbu u ispunjenju obveze preuzete nevaljanim ugovorom, a na obvezni odnos strana nevaljanog ugovora primjenjuju se i pravila o vraćanju stečenog bez osnove, odnosno pravila instituta neopravdanog obogaćenja. $U$ švicarskom, austrijskom i njemačkom pravu pronalaze se stajališta prema kojima je u trajnim obveznim odnosima u kojima se započelo s ispunjavanjem trajne obveze potrebno ograničiti učinak nevaljanosti ugovora na djelovanje samo za ubuduće. Prema njima, nevaljanost trajnog ugovora, odnosno ugovora kojim je zasnovan trajni obvezni odnos, nastupa ex nunc pa ne dolazi do povratnog odvijanja trajnoga obveznog odnosa. U radu se analiziraju stajališta švicarskoga, austrijskog $i$ njemačkog prava i teorijska uporišta na kojima su ona utemeljena. Raspravlja se o pravnim posljedicama nevaljanosti ugovora u hrvatskom pravu, a posebno o obvezi restitucije. Ispituje se je li u okvirima hrvatskoga prava de lege lata moguće i potrebno primijeniti poredbenopravno učenje o ograničavanju učinka nevaljanosti trajnog ugovora.
\end{abstract}

Ključne riječi: trajni obvezni odnos; trajni ugovor; nevaljanost ugovora; obveza restitucije.

\section{1. $U V O D$}

Ugovor kojim je među ugovornim stranama zasnovan trajni obvezni odnos označava se u ovom radu trajnim ugovorom. Trajni obvezni odnosi su obvezni odnosi u kojima je tipična glavna obveza trajna obveza, tj. obveza koja za predmet ima trajnu činidbu ili trajno ponavljanje jednokratnih činidbi. ${ }^{1}$ Jedna od njihovih ključnih posebnosti, prema obveznim odnosima koji su upravljeni na jednokratnu

* Dr. sc. Ivan Tot, poslijedoktorand, Ekonomski fakultet Sveučilišta u Zagrebu, itot@net.efzg.hr.

1 O određenju pojma trajnog obveznog odnosa sa stajališta hrvatskog, švicarskog, austrijskog i njemačkog prava: Tot, I., Pojam trajnog obveznog odnosa, Pravni vjesnik, vol. 34, 2/2018, str. 59-64. 
razmjenu činidbi, ogleda se u načinima i učincima njihova prestanka. ${ }^{2}$ Druga je njihova ključna posebnost, sa stajališta švicarskog, austrijskog i njemačkog prava, ograničavanje učinka nevaljanosti ugovora kojima se oni zasnivaju. U tim pravnim poredcima zastupljena su stajališta prema kojima je, u slučajevima u kojima se trajni obvezni odnos nalazi u stadiju odvijanja jer se već započelo s ispunjavanjem trajne obveze, učinak nevaljanosti trajnog ugovora ograničen na djelovanje samo pro futuro, odnosno prema kojima učinak nevaljanosti trajnog ugovora ne nastupa ex tunc, $\mathrm{u}$ trenutku njegova sklapanja. ${ }^{3}$ Trajni ugovor proizvodi namjeravane pravne učinke do trenutka isticanja njegove ništetnosti ili do trenutka njegova pobijanja zbog nekog od razloga pobojnosti, a u tom trenutku trajni obvezni odnos prestaje s ex nunc učinkom. Stoga nevaljanost trajnog ugovora ne dovodi do nastanka obveze vraćanja predmeta ranije izvršenih činidbi niti do povratnoga odvijanja (njem. Rückabwicklung) trajnoga obveznog odnosa primjenom pravila o neopravdanom obogaćenju (njem. ungerechtfertigte Bereicherung). ${ }^{4}$

Opće zakonsko uređenje nevaljanosti ugovora koje je u hrvatskom pravu sadržano u čl. 322.-335. ZOO-a ne sadrži izričite odredbe kojima bi se učinak nevaljanosti trajnog ugovora uređivao drukčije u odnosu na ostale ugovore. Ništetnost kao teži oblik nevaljanosti nastupa ex lege u trenutku sklapanja ugovora, odnosno ex tunc. Pobojnost kao lakši oblik nevaljanosti ne dovodi do nevaljanosti ugovora ex lege u trenutku njegova sklapanja, već pobojni ugovori proizvode namjeravane pravne učinke, ali se oni mogu poništiti s učinkom ex tunc. Pravne posljedice ništetnosti ugovora i poništenja pobojnoga ugovora do kojih dolazi ako se ispune dodatne zakonske pretpostavke su nastanak obveze restitucije te nastanak obveze naknade štete, a na obvezni odnos strana nevaljanog ugovora primjenjuju se i pravila

2 Trajna obveza ne može prestati ispunjenjem, već prestaje tek prestankom trajnoga obveznog odnosa, a on na redovni način može prestati redovnim otkazom i protekom vremena, dok na izvanredan način prestaje izvanrednim otkazom iz važnoga razloga. Ti načini prestanka trajnog obveznog odnosa djeluju pro futuro. O tome, sa stajališta hrvatskog, švicarskog, austrijskog i njemačkog prava: Tot, I., Prestanak trajnih obveznih odnosa, Zbornik Pravnog fakulteta Sveučilišta u Rijeci, vol. 39, 3/2018, str. 1171-1206.

3 Za švicarsko pravo: Binder, A., Geiser, T., Roberto, V., Einführung ins Privatrecht, St. Gallen, Universität St. Gallen, 2008., str. 56 i 61. Za austrijsko pravo: Barta, H. (ur.), Zivilrecht Grundriss und Einführung in das Rechtsdanken, Wien, Facultas Verlags- und Buchhandels, 2004., str. 343. Za njemačko pravo: Zerres, T., Bürgerliches Recht, Berlin - Heidelberg, Springer, 2010., str. 69. Podrobnije se na poredbenu pravnu književnost i sudsku praksu upućuje u bilješkama u drugom, trećem i četvrtom poglavlju.

4 Za institut neopravdanog obogaćenja u hrvatskom se pravu uvriježio naziv stjecanje bez osnove. U ovom se radu, posebno u poglavljima koja se bave analizom poredbenopravnih stajališta, radije rabi izraz neopravdano obogaćenje koji je uvriježen u poredbenom pravu. Naime, izraz stjecanje bez osnove ne opisuje adekvatno bit instituta neopravdanog obogaćenja. Stjecanje bez osnove je samo dio tog instituta, no u čl. 1111. st. 1. Zakona o obveznim odnosima (NN br. 35/05., 41/08., 125/11., 78/15. i 29/18.; dalje ZOO) taj je institut formalno izjednačen s jednom od kondikcija, condictio sine causa. O tome: Miladin, P., Odnos kondikcijskog i drugih srodnih imovinskopravnih zahtjeva, u: Uzelac, A. et al. (ur.), Djelotvorna pravna zaštita u pravičnom postupku, Zagreb, Pravni fakultet Sveučilišta u Zagrebu, 2013., str. 1083-1105; Miladin, P., Markovinović, H., Obogaćenje kao pretpostavka neopravdanog obogaćenja (stjecanja bez osnove), Zbornik Pravnog fakulteta u Zagrebu, vol. 68, 1/2018, str. 5-30. 
o stjecanju bez osnove. ${ }^{5}$

Uređenje obveznih odnosa u ZOO-u, kao i u poredbenom pravu, usmjereno je ponajprije na uređenje obveznih odnosa upravljenih na jednokratnu razmjenu činidbi, pa je potrebno ispitivati mogu li se pravni instituti primarno namijenjeni za te odnose primijeniti na trajne obvezne odnose izravno ili tek analogijom, odnosno mogu li se oni uopće na njih primijeniti. U hrvatskoj pravnoj književnosti nije razmatrano pitanje je li u trajnim obveznim odnosima potrebno, zbog njihove upravljenosti na trajnije obvezivanje, a ne na jednokratnu razmjenu činidbi, ograničiti učinak nevaljanosti ugovora i na koji način. Također, nedostaje i rasprava o poredbenopravnom učenju o ograničenju učinka nevaljanosti trajnog ugovora koje se u različitim smjerovima razvija u švicarskom, austrijskom i njemačkom pravu, na koje pravne poretke je hrvatsko obvezno pravo tradicionalno oslonjeno.

Stoga je predmetom rada analiza poredbenopravnih stajališta o ograničenju učinka nevaljanosti trajnog ugovora te ispitivanje primjenjivosti tih stajališta $u$ kontekstu hrvatskog prava de lege lata. Raspravlja se o različitim učenjima kojima se u promatranim poredcima utemeljuje gledište o ex nunc učinku nevaljanosti trajnog ugovora. U primjeni poredbenopravne metode se osim gledišta istaknutih u pravnoj književnosti analiziraju i odluke iz sudske prakse. Provodi se i analiza dostupnih odluka iz hrvatske sudske prakse o pravnim posljedicama nevaljanosti ugovora te ispituje na koji se način opće uređenje nevaljanosti primjenjuje u slučajevima u kojima je bio nevaljan trajni ugovor. Budući da se ključne posebnosti nevaljanosti trajnih ugovora, prema poredbenopravnim stajalištima, odnose na pravna pitanja trenutka u kojemu nastupa učinak nevaljanosti, nastanka obveze restitucije i primjene pravila o neopravdanom obogaćenju, no ne i na pravna pitanja odgovornosti za štetu, tom se pravnom posljedicom nevaljanosti ovaj rad podrobnije ne bavi.

Rad je strukturiran u šest poglavlja. Nakon uvodnog, u drugom, trećem i četvrtom poglavlju analiziraju se stajališta švicarskog, austrijskog i njemačkog prava o ograničenju učinka nevaljanosti trajnog ugovora. U petom se poglavlju najprije raspravlja o pojedinim manjkavostima prevladavajućih stajališta o pravnim posljedicama nevaljanosti ugovora u hrvatskom pravu, posebno onih koji se tiču obveze restitucije, a zatim se ispituje prihvatljivost poredbenopravnih gledišta o ograničenju učinka nevaljanosti trajnog ugovora za hrvatsko pravo de lege lata. Zaključci se iznose u šestom poglavlju rada.

5 Zagreb, O općem uređenju nevaljanosti ugovora u ZOO-u: Crnić, I., Zakon o obveznim odnosima, Organizator, 2016., str. 714-778.; Gorenc, V. (red.), Komentar Zakona o obveznim odnosima, Zagreb, Narodne novine, 2014., str. 513-538; Klarić, P., Vedriš, M., Građansko pravo, Zagreb, Narodne novine, 2009., str. 136-179; Radolović, A., Nevaljanost pravnih poslova, u: Baretić, M. et al., Novi Zakon o obveznim odnosima, Zagreb, Inženjerski biro, 2005., str. 88130; Slakoper, Z., Gorenc, V., Bukovac Puvača, M., Obvezno pravo - Opći dio - Sklapanje, promjene i prestanak ugovora, Zagreb, Novi informator, 2009., str. 312-346. Podrobnije se na hrvatsku pravnu književnost i sudsku praksu upućuje u bilješkama u petom poglavlju. 


\section{OGRANIČENJE UČINKA NEVALJANOSTI TRAJNOG UGOVORA U S̆VICARSKOM PRAVU}

Ništetnost ugovora prema općim pravilima u švicarskom pravu nastupa ex tunc, u trenutku sklapanja ugovora, pa ništetan ugovor ne proizvodi pravne učinke koje bi on proizvodio da je valjan. ${ }^{6}$ Jedna od pravnih posljedica ništetnosti je i nastanak obveze restitucije, pri čemu se prenesene stvari čije je vraćanje moguće vraćaju vindikacijom, a u ostalome se obvezni odnos strana ništetnog ugovora povratno odvija primjenom pravila o neopravdanom obogaćenju. ${ }^{7}$ Pobojni se ugovor pobija preobražajnim očitovanjem volje koje djeluje ex tunc zbog čega dolazi do povratnog odvijanja obveznog odnosa. ${ }^{8}$

Iznimka od općeg pravila o ex tunc učinku nevaljanosti sadržana je u odredbi čl. 320. st. 3. Obligacijskog zakonika9 ${ }^{9}$ kojom je uređen učinak nevaljanosti ugovora o radu. Prema toj odredbi, ako je radnik u dobroj vjeri obavio posao za poslodavca na temelju ugovora o radu za koji se naknadno utvrdilo da je nevaljan, obje ugovorne strane dužne su ispuniti svoje obveze iz radnog odnosa kao da je ugovor o radu bio valjan. ${ }^{10}$ Nevaljanost ugovora o radu proizvodi učinak ex nunc pa za ugovorne strane ne nastaje obveza vraćanja činidbi izvršenih prije isticanja ništetnosti ili pobijanja ugovora o radu. ${ }^{11}$

U pravnoj književnosti drži se da je tu odredbu potrebno analogijom primijeniti i na druge trajne obvezne odnose. ${ }^{12}$ Tako se pronalaze stajališta prema kojima ništetnost ugovora u svim trajnim obveznim odnosima $u$ kojima se započelo $s$ ispunjavanjem trajne obveze proizvodi samo ex nunc učinak te za posljedicu nema vraćanje već ispunjenog. ${ }^{13}$ Učinak ništetnosti trajnog ugovora ograničava se na djelovanje pro futuro kada je razlog ništetnosti izostanak propisanog oblika ugovora ${ }^{14}$ i kada je

6 Binder, A. et al., op. cit., str. 61; Gauch, P. et al., Schweizerisches Obligationenrecht Allgemeiner Teil - Band I, Zürich, Schulthess Polygraphischer Verlag, 1998., str. 131; Huguenin, C. u: Honsell, H. et al. (ur.), Basler Kommentar zum Schweizerischen Privatrecht - Obligationenrecht I, Basel - Genf - München, Helbing \& Lichtenhahn, 2003. (dalje: Basler Komm), str. 203; Schwenzer, I., Schweizerisches Obligationenrecht - Allgemeiner Teil, Bern, Stämpfli Verlag, 2003., str. 219.

7 Binder, A. et al., op. cit., str. 61; Gauch, P. et al., op. cit., str. 131-132; Schwenzer, I., op. cit., str. 223.

8 Binder, A. et al., op. cit., str. 69; Schwenzer, I., op. cit., str. 257-258; Schwenzer, I. u: Basler Komm, op. cit., str. 264-266.

9 Bundesgesetz vom 30. März 1911 betreffend die Ergänzung des Schweizerischen Zivilgesetzbuches (Fünfter Teil: Obligationenrecht), AS 27 317, s posljednjom izmjenom od 1. travnja 2017., AS 20172077 (dalje: OR).

10 O toj odredbi: Rehbinder, M., Portmann, W., u: Basler Komm, op. cit., str. 1680; Bucher, E., Schweizerisches Obligationenrecht - Allgemeiner Teil ohne Deliktsrecht, Zürich, Schulthess Polygraphischer Verlag, 1988., str. 274.

11 Huguenin, C., u: Basler Komm, op. cit., str. 204; Rehbinder, M., Portmann, W., u: Basler Komm, op. cit., str. 1680.

12 Binder, A. et al., op. cit., str. 56; Honsell, H., 100 Jahre Schweizerisches Obligationenrecht, Zeitschrift für schweizerisches Recht, vol. 130, 2/2011, str. 19; Schwenzer, I., op. cit., str. 12.

13 Binder, A. et al., loc. cit., Bucher, E., op. cit., str. 275.

14 Binder, A. et al., op. cit., str. 56; Schwenzer, I., op. cit., str. 204. 
sadržaj ugovora nemoguć ili nedopušten. ${ }^{15}$

Učinak pobijanja ugovora zbog nekog od razloga pobojnosti u trajnim obveznim odnosima u kojima se započelo s ispunjavanjem trajne obveze također je ograničen na djelovanje samo pro futuro. ${ }^{16} \mathrm{U}$ pravnoj književnosti do toga se dolazi primjenom odredbe čl. 320. st. 3. OR-a analogijom i na druge trajne obvezne odnose. ${ }^{17}$ Do istovjetnog se rješenja dolazi i teleološkom redukcijom odredaba OR-a o pobijanju ugovora iz razloga pobojnosti. ${ }^{18}$ Potreba teleološke redukcije obrazlaže se time što bi povratno odvijanje trajnog obveznog odnosa uz primjenu pravila o neopravdanom obogaćenju, zbog načelnog ex tunc učinka pobijanja ugovora, bilo gospodarski nerazumno imajući u vidu da su strane trajnog obveznog odnosa izvršavale činidbe kroz izvjesno duže vrijeme. ${ }^{19}$ Također se ukazuje da je do ograničenja učinka pobijanja trajnog ugovora, u slučajevima pobojnosti zbog bitne zablude, moguće doći i bez posezanja za teleološkom redukcijom, a uz primjenu odredbe čl. 25. st. 1. OR-a, prema kojoj nije dopušteno pozivanje na bitnu zabludu ako je ono protivno načelu savjesnosti i poštenja. ${ }^{20}$ Drži se da bi bilo protivno tom načelu, zbog toga što su sudionici trajnog obveznog odnosa izvjesno vrijeme izvršavali činidbe, izjaviti pobijanje trajnog ugovora zbog bitne zablude jer ona postoji već u trenutku njegova sklapanja. ${ }^{21}$

U ranijoj se švicarskoj sudskoj praksi stajalište o ograničenju učinka nevaljanosti trajnog ugovora na djelovanje pro futuro, u slučajevima u kojima se započelo $\mathrm{s}$ ispunjavanjem trajne obveze, dogmatski utemeljivalo s pomoću učenja o faktičnim ugovornim odnosima (njem. faktische Vertragsverhältnisse) ${ }^{22}$ Prema tom učenju se iz različitih pravnopolitičkih razloga uzima da su nastali učinci valjano sklopljenog ugovora, iako strane faktičnog ugovornog odnosa nisu sklopile nikakav ugovor ili ga nisu sklopile valjano. ${ }^{23}$ Tako je u jednom predmetu u kojemu su bile sporne posljedice nevaljanosti ugovora o leasingu, a koji je bio ništetan zbog izostanka propisanog sadržaja, švicarski Savezni sud (njem. Bundesgericht; dalje: BGE) utvrdio da je između strana tog ništetnog ugovora postojao faktični ugovorni odnos u razdoblju

15 Binder, A. et al., op. cit., str. 61, Schwenzer, I., loc. cit.

16 Bucher, E., op. cit., str. 27.; Honsell, H., loc. cit. u bilj. 12; Schwenzer, I. u: Basler Komm, op. cit., str. 232, Schwenzer, I., op. cit., str. 12 i 257; Wiegand, W., Zur Rückabwicklung gescheiterter Verträge, u: Tercier, P., at al., Gauchs Welt - Festschrift für Peter Gauch zum 65. Geburtstag, Zürich, Schulthess, 2004., str. 720.

17 Schwenzer, I., u: Basler Komm, op. cit., str. 232; Schwenzer, I., op. cit., str. 12.

18 ibid.

19 ibid.

20 Schwenzer, I., u: Basler Komm, op. cit., str. 233 i 248; Schwenzer, I., op. cit., str. 257.

21 Gauch, P. et al., op. cit., str. 191; Schwenzer, I., u: Basler Komm, op. cit., str. 248.-249; Schwenzer, I., op. cit., str. 257.

22 Bucher, E., op. cit., str. 275; Gauch, P. et al., op. cit., str. 250; Schwenzer, I., op. cit., str. 185 i 204; Schwenzer, I., Rezeption deutschen Rechtsdenkens im schweizerischen Obligationenrecht, u: Schwenzer, I. (ur.), Schuldrecht, Rechtsvergleichung und Rechtsvereinheitlichung an der Schwelle zum 21. Jahrhundert, Tübingen, Mohr Siebeck, 1999., str. 78.

23 O tom učenju: Bucher, E., op. cit., str. 270-276; Gauch, P. et al., op. cit., str. 249-252; Schwenzer, I., op. cit., str. 184-186; Schwenzer, I., op. cit., str. 76-79. 
dužem od tri godine tijekom kojega su one ispunjavale obveze iz ništetnog ugovora. ${ }^{24}$ BGE je odbio zahtjev primatelja leasinga za vraćanjem plaćenog iznosa naknade za leasing s obrazloženjem da je davatelj leasinga ovlašten taj iznos zadržati kao naknadu za primateljevo korištenje motornog vozila tijekom predmetnog razdoblja. U dijelu pravne književnosti se primjena učenja o faktičnim ugovornim odnosima radi ograničenja učinka nevaljanosti trajnog ugovora drži suvišnom jer se istovjetno može postići teleološkom redukcijom odredaba OR-a, kao i primjenom odredbe čl. 320. st. 3. OR-a analogijom na druge trajne obvezne odnose. ${ }^{25}$

U novijoj se sudskoj praksi stajalište o ex nunc učinku nevaljanosti trajnog ugovora ne utemeljuje na učenju o faktičnim ugovornim odnosima, već se do ograničenja učinka nevaljanosti dolazi teleološkom redukcijom odredaba OR-a. Tako je u jednom predmetu BGE odlučio da očitovanje volje kojim jedna strana pobija trajni ugovor proizvodi učinak ex nunc jer se izjava o pobijanju uzima kao izvanredni otkaz ugovora. ${ }^{26} \mathrm{U}$ tom predmetu bili su sporni učinci izjave o pobijanju ugovora o odlaganju kanalizacijskog mulja kojom je taj ugovor pobijan zbog toga što je do njegova sklapanja došlo zbog mita druge strane. Utvrdivši da je tim ugovorom bio zasnovan trajni obvezni odnos u kojemu su strane do trenutka pobijanja izvršavale činidbe čije bi vraćanje bilo povezano sa znatnim praktičnim poteškoćama, BGE je zauzeo stajalište da izjava o pobijanju proizvodi ex nunc učinak kao da je riječ o izvanrednom otkazu ugovora te da je posljedično ugovor u potpunosti valjan u dijelu u kojemu je on do pobijanja bio ispunjavan. Potrebu ograničenja učinka pobijanja trajnog ugovora koji se nalazi u stadiju odvijanja BGE je obrazložio time što povratno odvijanje trajnog obveznog odnosa primjenom pravila o neopravdanom obogaćenju nailazi na znatne praktične poteškoće, a često se pokazuje i nemogućim. Istaknuo je i da to što zakonodavac nije odredbu čl. 320. st. 3. OR-a izričito protegnuo i na druge trajne obvezne odnose ne priječi sud da teleološkim tumačenjem uopći pravilo iz te odredbe i analogijom ga primijeni na druge trajne obvezne odnose. Prema stajalištu BGE-a, pretpostavka za ograničenje učinka pobijanja trajnog ugovora na djelovanje ex nunc jest da se razlog pobojnosti nije odrazio u kvantitativnom smislu na odnos glavne činidbe i protučinidbe. U konkretnom je predmetu strana koja je pobijala ugovor bila u zabludi o odlučnim okolnostima sklapanja ugovora, no to za posljedicu nije imalo ugovaranje višega iznosa njezine protučinidbe od onoga koji bi bio ugovoren da nije bilo te zablude, odnosno da je ugovor sklopljen bez davanja mita druge strane. Razmatrajući pitanje moguće primjene učenja o faktičnim ugovornim odnosima, BGE je istaknuo da bi primjena tog učenja u konkretnom slučaju dovela do istovjetnog rezultata do kojeg se došlo postupajući s izjavom o pobijanju ugovora kao s izvanrednim otkazom ugovora, kao i da je prihvaćanje tog učenja u kontekstu učinka pobijanja ugovora suvišno, pogotovo zbog toga što se pobijanje ostvaruje preobražajnim očitovanjem volje, a ne sudskom odlukom. Kao primjere trajnih ugovora u kojima povratno odvijanje trajnog obveznog odnosa zbog načelnog ex tunc

24 BGE, 110 II 244 od 5. rujna 1984. Sve u radu navedene odluke BGE dostupne su na: Bundesgericht Rechtsprechung, <https://www.bger.ch/index.htm>, 19. siječnja 2019.

25 Schwenzer, I., op. cit., str. 186 i 204-205.

26 BGE, 129 III 320 od 21. veljače 2003. 
učinka nevaljanosti uobičajeno nailazi na znatne praktične poteškoće, BGE je u toj odluci istaknuo ugovore o službi, naplatnom prepuštanju na uporabu, doživotnom uzdržavanju te ortaštvu. U jednoj kasnijoj odluci je istaknuo da povratno odvijanje trajnog obveznog odnosa nailazi na ograničenje u slučaju u kojemu izvršenu činidbu nije moguće vratiti in natura, a takva je činidba koja ima oblik činjenja ili propuštanja. ${ }^{27}$

Ranije stajalište da je odredbu čl. 320. st. 3. OR-a moguće uopćeno primijeniti analogijom i na druge trajne obvezne odnose, BGE je potvrdio i u jednoj odluci koja se ticala pravnih posljedica pobijanja ugovora o radu zbog prijevare. ${ }^{28} \mathrm{Tu}$ je on potvrdio i ranije stajalište da je s izjavom o pobijanju trajnog ugovora potrebno postupiti kao s izvanrednim otkazom ugovora.

U drugoj se odluci BGE, u predmetu u kojemu je trajni ugovor bio ništetan zbog protivnosti njegova sadržaja prisilnim propisima, bavio pitanjem mogu li se praktične poteškoće s povratnim odvijanjem trajnog obveznog odnosa do kojih dolazi primjenom pravila o neopravdanom obogaćenju, a koje opravdavaju ograničenje učinka nevaljanosti trajnog ugovora, otkloniti drukčije. ${ }^{29}$ Zaključio je da je opravdano, zbog toga što u slučaju povratnog odvijanja trajnog obveznog odnosa primjenom pravila o neopravdanom obogaćanju redovito nije sasvim jednostavno utvrditi tržišnu vrijednost činidaba koje imaju oblik propuštanja i činjenja, trajni obvezni odnos povratno odviti prihvaćanjem subjektivne procjene vrijednosti izvršenih činidaba koju su sastavile strane.

\section{OGRANIČENJE UČINKA NEVALJANOSTI TRAJNOG UGOVORA U AUSTRIJSKOM PRAVU}

Ništetnost ugovora te poništenje ugovora zbog nekog od razloga pobojnosti i u austrijskom pravu načelno proizvode učinak ex tunc. ${ }^{30}$ Opći građanski zakonik ${ }^{31}$ ne sadrži odredbe kojima bi se učinak nevaljanosti uređivao drukčije ni za trajne ugovore općenito niti za pojedine tipove trajnih ugovora zasebno. Međutim, stajalište prema kojemu nevaljanost trajnog ugovora ima ex nunc učinak prihvaćeno je i u austrijskom pravu. Značajka je austrijskoga prava što je to stajalište prvotno bilo prihvaćeno kao opće pravilo koje se primjenjuje na sve trajne ugovore, a zatim je doseg toga pravila u sudskoj praksi i pravnoj književnosti postupno sve više sužavan izdvajanjem iznimaka u kojima nevaljanost trajnog ugovora ipak nastupa ex tunc.

Gledište o potrebi ograničenja učinka nevaljanosti trajnog ugovora u austrijskoj je pravnoj književnosti prvi izrazio Gschnitzer. Prema njemu, opća pravila o nevaljanosti ugovora nisu primjenjiva na trajne obvezne odnose nakon što se započelo $\mathrm{s}$ ispunjavanjem trajne obveze, već se u tim odnosima razlozi nevaljanosti pretvaraju

27 BGE, 137 III 243 od 3. svibnja 2011.

28 BGE, 132 III 242 od 23. studenoga 2005.

29 BGE, 134 III 438 od 12. lipnja 2008.

30 Vidi, primjerice: Bydlinski, P., Bürgerliches Recht - Band I - Allgemeiner Teil, Wien - New York, Springer, 2007., str. 144 i 180.

31 Allgemeines bürgerliches Gesetzbuch für die gesammten deutschen Erbländer der Oesterreichischen Monarchie, JGS br. 946/1811., s posljednjom izmjenom od 22. prosinca 2018., BGB1 I br. 100/18. (dalje: ABGB). 
u važne razloge za izvanredni otkaz koji djeluje samo pro futuro. ${ }^{32}$ Stoga ništetnost i poništenje trajnog ugovora proizvode učinak ex nunc, od primitka izvanrednog otkaza iz važnoga razloga kojim se gasi trajna obveza i trajni obvezni odnos prestaje, pa ne dolazi do obveze restitucije ni do primjene pravila o neopravdanom obogaćenju. Takvo je opće stajalište zastupljeno ponegdje i danas. ${ }^{33}$

U ranijoj je sudskoj praksi Gschnitzerovo gledište bilo prihvaćeno bez ograničenja. Tako je austrijski Vrhovni sud (njem. Oberster Gerichtshof; dalje: OGH) u nekoliko predmeta odlučio da zabluda poslodavca ne može, nakon što je radni odnos faktično započeo, biti razlogom za poništenje ugovora o radu s učinkom ex tunc, već samo razlogom za prestanak ugovora o radu s učinkom ex nunc, s obrazloženjem da u faktičnom radnom odnosu postoje posebne društvene veze kojima je potrebno priznati istovjetne učinke kao i radnom odnosu zasnovanom valjanim ugovorom o radu. ${ }^{34}$ Stajalište prema kojemu se razlozi pobojnosti pretvaraju u važne razloge za izvanredni otkaz ugovora s učinkom ex nunc, OGH je zauzeo i u pogledu trajnih obveznih odnosa, u kojima se bilo otpočelo s ispunjavanjem trajne obveze, zasnovanih drugim tipovima trajnih ugovora, pa tako, primjerice, ugovorom o zakupu benzinske crpke, ${ }^{35}$ ugovorom o distribuciji ${ }^{36}$ te ugovorom o licenciji. ${ }^{37}$

Kasnija sudska praksa i pravna književnost u nekoliko su pogleda odstupili od prvotnog gledišta, prema kojemu poništenje trajnog ugovora iz bilo kojega razloga pobojnosti proizvodi ex nunc učinak. Tako je OGH u nizu predmeta zauzeo stajalište prema kojemu poništenje trajnog ugovora ipak proizvodi ex tunc učinak u slučajevima pobojnosti ugovora zbog prijevare, s obrazloženjem da bi poništenje $\mathrm{s}$ ex nunc učinkom neopravdano dovodilo do toga da je strana koja je postupila prijevarno uspjela s prijevarom i njome ostvarila korist. ${ }^{38}$ Istovjetno se ističe u pravnoj književnosti u kojoj se među razlozima pobojnosti koji dovode do poništenja trajnog ugovora s učinkom ex tunc, osim prijevare, ističe i prijetnja. ${ }^{39}$

Također, prema stajalištu OGH i poništenje trajnog ugovora zbog zablude ipak može djelovati ex tunc ako je riječ o trajnom obveznom odnosu u kojemu su izvršene činidbe koje su za stranu koja se poziva na zabludu bile neuporabljive,

32 Gschnitzer, F., Allgemeiner Teil des bürgerlichen Rechts, Wien, Springer Verlag, 1966., str. 160-161.

33 Barta, H., op. cit., str. 343, 350, 391 i 395.

34 OGH, 4 Ob 138/62 od 27. studenoga 1962., 4 Ob 57/68 od 5. studenoga 1968. i 4 Ob 76/82 od 26. travnja 1983. Sve u radu navedene odluke OGH dostupne su na: Bundeskanzleramt Rechtsinformationssystem - Justiz, <https://www.ris.bka.gv.at/>, 19. siječnja 2019.

35 OGH, 4 Ob 141/84 od 28. siječnja 1986.

36 OGH, $1 \mathrm{Ob} 650 / 88$ od 11. listopada 1988.

37 OGH, 7 Ob 515/95 od 27. siječnja 1995.

38 OGH, 3 Ob 516/90 od 13. lipnja 1990., 2 Ob 131/97x od 26. lipnja 1997., 6 Ob 81/99a od 28. svibnja 1999., 6 Ob 257/08z od 17. prosinca 2008. i 1 Ob 122/18z od 26. rujna 2018.

39 Koziol, H., Welser, R., Kletečka, A., Grundriss des bürgerlichen Rechts - Band I - Allgemeiner Teil, Sachenrecht, Familienrecht, Wien, MANZ'sche Verlags- und Universitätsbuchhandlung, 2014., str. 177; Pletzer, R. u: Kletečka, A., Schauer, M. (ur.), ABGB-ON - Kommentar zum Allgemeinen bürgerlichen Gesetzbuch, Wien, Manzsche Verlags- und Universitätsbuchhandlung, 2010., str. 1654; Wiebe, A., u: ibid., str. 1548. 
odnosno beskorisne ${ }^{40}$ Primjerice, u jednom je predmetu jedna strana zahtijevala poništenje ugovora kojim joj se druga strana obvezala pružati usluge ozonske terapije u svrhu mršavljenja, pozivajući se da je pri sklapanju tog ugovora bila u zabludi da će ozonska terapija polučiti očekivani rezultat sama po sebi, bez dodatne tjelovježbe i korekcija u prehrani. Premda je među stranama bio zasnovan trajni obvezni odnos, OGH je poništio ugovor s učinkom ex tunc te obvezao drugu stranu na vraćanje iznosa naknade za pružene usluge ozonske terapije s obrazloženjem da bi ograničenje poništenja ugovora na ex nunc učinak u konkretnom slučaju dovelo do neopravdanog honoriranja beskorisnih činidaba. ${ }^{41}$

Pretpostavke za ograničenje učinka poništenja ugovora zbog zablude na djelovanje ex nunc su da je riječ o trajnom obveznom odnosu koji se zbog započetog ispunjavanja trajne obveze nalazi u stadiju odvijanja te da je povratno odvijanje obveznog odnosa otežano ili nemoguće. Ako se trajni obvezni odnos još ne nalazi u stadiju odvijanja, odnosno ako se nije započelo s ispunjavanjem trajne obveze, trajni je ugovor moguće poništiti s ex tunc učinkom. ${ }^{42} \mathrm{U}$ nizu je odluka OGH zauzeo stajalište prema kojemu će poništenje trajnog ugovora ipak imati ex tunc učinak ako je trajni obvezni odnos, unatoč tome što se nalazi u stadiju odvijanja, moguće povratno odviti bez većih poteškoća ${ }^{43}$ Redovito je prema stajalištu OGH moguće bez većih poteškoća povratno odviti trajni obvezni odnos zasnovan ugovorom o najmu i ugovorom o zakupu. ${ }^{44}$ To ne znači da bi poništenje ugovora o najmu ili ugovora o zakupu uvijek trebalo djelovati ex tunc. Naime, odgovor na pitanje postoje li poteškoće s povratnim odvijanjem trajnog obveznog odnosa (njem. Rückabwicklungsschwierigkeiten) ovisi o konkretnim okolnostima svakoga pojedinog slučaja. ${ }^{45}$

Osim tih iznimaka od gledišta prema kojemu poništenje trajnog ugovora zbog zablude proizvodi ex nunc učinak, u pravnoj se književnosti zastupa i stajalište prema kojemu bi poništenje trajnog ugovora trebalo djelovati ex tunc i ako se zabluda odrazila na odmjeravanje iznosa protučinidbe, odnosno ako je strana u zabludi pristala na protučinidbu u višem iznosu nego što bi on bio ugovoren da zablude nije bilo. ${ }^{46}$

$\mathrm{S}$ iznimkom pojedinih ranijih odluka o ex nunc učinku poništenja ugovora o radu u kojima se OGH pozvao na postojanje faktičnog radnog odnosa, ${ }^{47}$ učenje o faktičnim ugovornim odnosima redovito nije bilo argument na koji bi se OGH pozivao u odlukama u kojima je zauzimao stajalište o ex nunc učinku poništenja trajnog

40 OGH, 1 Ob 2169/96v od 26. studenoga 1996., 2 Ob 131/97x od 26. lipnja 1997. i 6 Ob 69/08b od 2. srpnja 2009.

41 OGH, 2 Ob 131/97x od 26. lipnja 1997.

42 OGH, 1 Ob 62/71 od 13. svibnja 1971. i 1 Ob 2169/96v od 26. studenoga 1996.

43 OGH, 1 Ob 27/89 od 15. studenoga 1989., 1 Ob 2169/96v od 26. studenoga 1996., 2 Ob 131/97x od 26. lipnja 1997., 6 Ob81/99a od 28. svibnja 1999., 6 Ob 257/08z od 17. prosinca 2008., $6 \mathrm{Ob}$ 69/08b od 2. srpnja 2009. i 1 Ob 122/18z od 26. rujna 2018.

44 OGH, 8 Ob 276/71 od 16. studenoga 1971., 7 Ob 533/82 od 15. lipnja 1982., 7 Ob 689/82 od 27. siječnja 1983., 1 Ob 27/89 od 15. studenoga 1989., 6 Ob 691/89 od 18. siječnja 1990., 5 Ob 508/95 od 14. ožujka 1995., 7 Ob 533/82 od 15. lipnja 1982. i 6 Ob 81/99a od 28. svibnja 1999.

45 OGH, 6 Ob 81/99a od 28. svibnja 1999.

46 Koziol, H. et al., loc. cit. u bilj. 39; Pletzer, R., u: Kletečka, A., Schauer, M., op. cit., str. 16541655.

47 Vidi supra u bilj. 34. 
ugovora. Stajališta OGH i pravne književnosti o ex nunc učinku poništenja trajnog ugovora utemeljuju se na potrebi teleološke redukcije odredaba ABGB-a o ex tunc učinku poništenja ugovora koja se opravdava poteškoćama s povratnim odvijanjem trajnog obveznog odnosa. Kao dodatni argument za ex nunc učinak poništenja ugovora o radu redovito se ističe potreba zaštite radnika i specifična zaštitna svrha radnog prava ${ }^{48}$ Faktično postojanje i djelovanje društva te posebna potreba zaštite vjerovnika i članova društva ističu se kao dodatni argumenti za ograničenje učinka poništenja ugovora o osnivanju društva na djelovanje samo za ubuduće. ${ }^{49}$

Prevladavajuće stajalište današnje austrijske pravne književnosti jest da poništenje ugovora zbog nekog od razloga pobojnosti u trajnim obveznim odnosima u kojima se započelo s ispunjavanjem trajne obveze proizvodi ex nunc učinak, osim ako je riječ o poništenju trajnog ugovora zbog prijevare ili prijetnje te ako je riječ o slučajevima u kojima ne postoje poteškoće s povratnim odvijanjem trajnog obveznog odnosa..$^{50}$ Nasuprot tomu, u dijelu pravne književnosti zabilježeno je i stajalište prema kojemu ne postoje nikakvi opravdani razlozi za ograničenje učinka poništenja trajnog ugovora te bi se i na poništenje trajnog ugovora trebala primjenjivati ista opća pravila kao i za druge ugovore. ${ }^{51}$

Za razliku od poništenja trajnog ugovora zbog nekog od razloga pobojnosti, stajalište austrijskog prava u pogledu učinaka ništetnosti trajnog ugovora nije sasvim izvjesno. S jedne strane, poteškoće s povratnim odvijanjem trajnog obveznog odnosa javljaju se u sudskoj praksi i pravnoj književnosti kao argument i za ex nunc učinak ništetnosti trajnog ugovora u slučajevima u kojima se započelo $\mathrm{s}$ ispunjavanjem trajne obveze. ${ }^{52} \mathrm{~S}$ druge strane, OGH je u jednom predmetu koji se odnosio na pravne posljedice ništetnosti ugovora o radu zauzeo i stajalište da ništetnost tog ugovora nastupa ex tunc, a da na mjesto obveze vraćanja izvršenih činidbi primjenom pravila o neopravdanom obogaćenju stupa obveza naknade vrijednosti činidbi čije vraćanje nije više moguće. ${ }^{53}$

48 Marhold, F., Friedrich, M., Österreichisches Arbeitsrecht, Wien - New York, Springer, 2012., str. 24.

49 OGH, 1 Ob 685/90 od 18. rujna 1991., 8 Ob 12/93 od 16. rujna 1993., 8 Ob 39/95 od 8. veljače 1996., 5 Ob 2267/96k od 8. listopada 1996., 8 Ob S315/97z od 13. siječnja 1998. i 7 Ob 77/10i od 30. ožujka 2011.

50 Bollenberger, R. u: Koziol, H., Bydlinski, P., Bollenberger, R. (ur.), Kurzkommentar zum ABGB, Wien - New York, Springer, 2010., str. 831; Kolmasch, W., u: Schwimann, M. (ur.), ABGB Taschenkommentar, Wien, LexisNexis Verlag, 2013., str. 603 i 608; Koziol, H. et al., op. cit., str. 176-177; Lurger, B. u: Kletečka, A. i Schauer, M., op. cit., str. 3867; Pletzer, R. u: Kletečka, A., Schauer, M., op. cit., str. 1654; Wiebe, A. u: Kletečka, A. i Schauer, M., op. cit., str. 1548.

51 Bydlinski, P., op. cit., str. 180.

52 OGH, 8 Ob 644/91 od 10. rujna 1992., 2 Ob 511/95 od 23. veljače 1995., 4 Ob 233/00v od 24. listopada 2000. i 5 Ob 193/17v od 20. studenoga 2017.; Wiebe, A., u: Kletečka, A., Schauer, M., op. cit., str. 1548.

53 OGH, 4 Ob 67/83 od 25. rujna 1984. 


\section{OGRANIČENJE UČINKA NEVALJANOSTI TRAJNOG UGOVORA U NJEMAČKOM PRAVU}

U njemačkom pravu ništetnost i pobijanje ugovora zbog nekog od razloga pobojnosti prema općim pravilima djeluju ex tunc, od trenutka sklapanja ugovora, a izvršene činidbe vraćaju se primjenom pravila o neopravdanom obogaćenju. ${ }^{54} \mathrm{U}$ Građanskom zakoniku ${ }^{55}$ nisu sadržane odredbe kojima bi se učinak nevaljanosti trajnih ugovora uređivao drukčije u odnosu na opća pravila. Stajalište o potrebi ograničenja učinka nevaljanosti u slučajevima u kojima se započelo s ispunjavanjem trajne obveze zastupljeno je i u njemačkom pravu, ali se ono u usporedbi sa švicarskim i austrijskim pravom odnosi na znatno uži krug slučajeva.

Prevladavajuće je gledište u sudskoj praksi Saveznoga radnog suda (njem. Bundesarbeitsgericht; dalje: BAG) i u pravnoj književnosti da je zbog posebnosti radnoga odnosa opravdano ograničiti učinak ništetnosti ugovora o radu samo za ubuduće. Prema učenju o manjkavom ugovoru o radu (njem. Lehre vom fehlerhaften Arbeitsvertrag), ništetnost ugovora o radu ako je radnik nakon sklapanja ugovora počeo s obavljanjem posla za poslodavca u pravilu ima učinak ex nunc pa ne dolazi do povratnog odvijanja radnog odnosa primjenom pravila o neopravdanom obogaćenju. ${ }^{56}$ Iznimno, zbog osobito teških razloga ništetnosti ugovora o radu, kao što je to, primjerice, protivnost moralu, ništetnost ipak nastupa ex tunc. ${ }^{57}$ Pobijanje ugovora o radu zbog razloga pobojnosti također proizvodi samo ex nunc učinak. ${ }^{58}$ Međutim, ako

54 Vidi, primjerice: Zerres, T., loc. cit. u bilj. 3.

55 Bürgerliches Gesetzbuch in der Fassung der Bekanntmachung vom 2. Januar 2002, BGB1 I br. 2/02., s posljednjom izmjenom od 12. srpnja 2018., BGB1 I br. 26/18. (dalje: BGB).

56 BAG, 1 AZR 189/57 od 15. studenoga 1957., 2 AZR 145/67 od 18. travnja 1968. i 5 AZR 592/03 od 3. studenoga 2004. Sve u radu navedene odluke iz njemačke sudske prakse, ako nije drukčije naznačeno, dostupne su na: Jurion - Das Rechtsportal, <https://www.jurion.de/>, 19. siječnja 2019. U pravnoj književnosti vidi: Armbrüster, C. u: Schubert, C. (red.), Münchener Kommentar zum Bürgerlichen Gesetzbuch: BGB Band 1: Allgemeiner Teil, München, C. H. Beck, 2018., § 138, odl. 162.; Benecke, M., u: Kiel, H. et al. (red.), Münchener Handbuch zum Arbeitsrecht - Individualarbeitsrecht I, München, C. H. Beck, 2018., § 38, odl. 48.; Hromadka, W., Maschmann, F., Arbeitsrecht - Band 1 - Individualarbeitsrecht, Berlin - Heidelberg, Springer, 2015., str. 180-181; Linck, R., u: Schaub, G. (red.), Arbeitsrechts-Handbuch, München, C. H. Beck, 2017., § 34, odl. 51.; Putzo, H. u: Palandt, O. (red.), Palandt - Bürgerliches Gesetzbuch, München, C. H. Beck, 2003., str. 872; Richardi, R., Dienstvertrag, u: Martinek, M. (red.), J. von Staudingers Kommentar - Eckpfeiler des Zivilrechts, Berlin, Sellier - de Gruyter, 2010., str. 696; Wentdland, H. u: Bamberger, H. G. et al. (ur.), Beck'scher Online-Kommentar Bürgerliches Gesetzbuch, München, C. H. Beck, 2017., § 142, odl. 6.

57 BAG, 5 AZR 512/71 od 7. lipnja 1972. i 5 AZR 592/03 od 3. studenoga 2004.; Armbrüster, C., u: Schubert, C., loc. cit. u bilj. 56; Hromadka, W., Maschmann, F., op. cit., str. 181; Linck, R., u: Schaub, G., op. cit., § 34, odl. 52.

58 BAG, 2 AZR 228/80 od 16. rujna 1982. i 7 AZR 34/83 od 29. kolovoza 1984.; Boemke, B., Ulrici, B., BGB Allgemeiner Teil, Berlin - Heidelberg, Springer, 2014., str. 293; Busche, J. u: Schubert, C., op. cit., § 142, odl. 17.-18.; Dörner, H. u: Schulze, R. (red.), Bürgerliches Gesetzbuch - Handkommentar, Baden-Baden, Nomos, 2019., § 119, odl. 2. i § 142, odl. 6.; Heinrichs, H., u: Palandt, O., op. cit., str. 154; Hromadka, W., Maschmann, F., op. cit., str. 186-187; Linck, R. u: Schaub, G., op. cit., § 34, odl. 49.; Mansel, H.-P. u: Stürner, R. (red.), Jauernig - Bürgerliches Gezetzbuch: Kommentar, München, C. H. Beck, 2018., Vor. § 630, odl. 
je razlog pobojnosti prijevara, pobijanje ugovora o radu ipak će imati ex tunc učinak. ${ }^{59}$

Također, prema stajalištima zastupljenim u odlukama Saveznog vrhovnog suda (njem. Bundesgerichtshof; dalje: BGH) i u pravnoj književnosti, ništetnost ugovora o osnivanju društva te pobijanje ugovora o osnivanju društva iz razloga pobojnosti proizvode ex nunc učinak.$^{60}$ Ograničenje učinaka nevaljanosti ugovora o osnivanju društva opravdava se potrebom zaštite članova društva i zaštite trećih osoba koje su s povjerenjem u postojanje društva stupile $s$ njim u odnose te potrebom olakšane likvidacije društva s nedostatkom (njem. fehlerhafte Gesellschaft) prema pravilima prava društava.$^{61}$

Gledište o ograničenom učinku nevaljanosti ugovora o radu i ugovora o osnivanju društva u njemačkom se pravu ne utemeljuje na učenju o faktičnim ugovornim odnosima. Premda je to učenje izvorno nastalo u njemačkoj pravnoj znanosti, ono je danas, za razliku od švicarskog prava, u okvirima njemačkoga prava napušteno. ${ }^{62}$ Ograničenje učinka nevaljanosti ugovora o radu i ugovora o osnivanju društva u njemačkom se pravu utemeljuje na teleološkoj redukciji odredaba BGB-a o ex tunc učinku nevaljanosti ugovora. ${ }^{63}$ Takva se teleološka redukcija ne opravdava praktičnim poteškoćama zbog kojih bi povratno odvijanje trajnog obveznog odnosa bilo otežano, već specifičnim odnosom međuovisnosti ugovornih strana i naglašenom potrebom socijalne zaštite zbog koje ne bi bilo opravdano povratno odviti trajni obvezni odnos prema pravilima o neopravdanom obogaćenju. ${ }^{64}$

U njemačkom pravu ne postoji opće pravilo prema kojemu se bilo koji trajni obvezni odnos ne bi mogao povratno odviti primjenom pravila o neopravdanom obogaćenju. ${ }^{65} \mathrm{Uz}$ iznimke za ugovor o radu i ugovor o osnivanju društva, ništetnost

5.; Putzo, H., u: Palandt, O., loc. cit. u bilj. 56; Richardi, R., u: Martinek, M., loc. cit. u bilj. 56; Stoffels, M., u: Rolfs, C. et al. (red.), Beck'scher Online-Kommentar Arbeitsrecht, München, C. H. Beck, 2018., § 626, odl. 14.; Wentdland, H., u: Bamberger, H. G. et al., loc. cit. u bilj. 56.

59 BAG, 2 AZR 754/97 od 3. prosinca 1998.; Busche, J., u: Schubert, C., op. cit., § 142, odl. 18.; Hromadka, W. i Maschmann, F., op. cit., str. 187; Linck, R. u: Schaub, G., op. cit., § 34, odl. 50.; Richardi, R. u: Martinek, M., loc. cit. u bilj. 56.

60 BGH, II ZR 18/51 od 24. listopada 1951., II ZR 167/53 od 12. svibnja 1954., II ZR 82/70 od 14. prosinca 1972., II ZR 127/74 od 11. ožujka 1976. i XI ZR 252/08 od 10. studenoga 2009.; Armbrüster, C., u: Schubert, C., loc. cit. u bilj. 56; Boemke, B. i Ulrici, B., loc. cit. u bilj. 58; Busche, J., u: Schubert, C., op. cit., § 142, odl. 17. i 19.; Dörner, H., u: Schulze, R., loc. cit. u bilj. 58; Heinrichs, H., u: Palandt, O., op. cit., str. 154; Sprau, H., u: Palandt, O., op. cit., str. 1082-1083; Stürner, R., u: Stürner, R., op. cit., § 705, odl. 19.

61 Larenz, K. i Canaris, C.-W., Methodenlehre der Rechtswissenschaft, Berlin - Heidelberg, Springer, 1995., str. 215; Sprau, H., u: Palandt, O., op. cit., str. 1082; Stürner, R., u: Stürner, R., op. cit., § 705, odl. 19.; Zerres, T., op. cit., str. 69.

62 Flume, W., Allgemeiner Teil des Bürgerlichen Rechts - Zweiter Band - Das Rechtsgeschäft, Berlin - Heidelberg, Springer, 1992., str. 101-102; Kramer, E. A., Der Einfluß des BGB auf das schweizerische und österreichische Privatrecht, Archiv für die civilistische Praxis, vol. 200, 3-4/2000, str. 382; Schiemann, G., Das Rechtsgeschäft, u: Martinek, M., op. cit., str. 52-53.

63 Boemke, B., Ulrici, B., loc. cit.; Larenz, K., Canaris, C.-W., loc. cit. u bilj. 61; Schiemann, G. u: Martinek, M., op. cit., str. 53.

64 Oetker, H., Maultzsch, F., Vertragliche Schuldverhältnisse, Berlin - Heidelberg - New York, Springer, 2013., str. 466.

65 Armbrüster, C. u: Schubert, C., loc. cit. u bilj. 56; Busche, J., u: Schubert, C., op. cit., § 142, odl. 
i pobijanje trajnog ugovora zbog razloga pobojnosti djeluju ex tunc i u trajnim obveznim odnosima u kojima se započelo s ispunjavanjem trajne obveze. Drži se da poteškoće s povratnim odvijanjem trajnog obveznog odnosa u kojemu se započelo $\mathrm{s}$ ispunjavanjem trajne obveze ne opravdavaju modifikaciju učinka nevaljanosti ugovora ${ }^{66}$ Tako nevaljanost ugovora o najmu i ugovora o zakupu načelno nastupa ex tunc, unatoč mogućim poteškoćama s povratnim odvijanjem njima zasnovanih trajnih obveznih odnosa. ${ }^{67}$ Prema stajalištu BGH izraženom u jednoj odluci, u zakupnim odnosima u pravilu ne postoji specifična društvena vezanost strana kakva postoji u trajnim obveznim odnosima zasnovanim ugovorom o radu i ugovorom o osnivanju društva pa nije opravdano ograničiti učinak pobijanje ugovora o zakupu poslovnog prostora na djelovanje ex nunc. ${ }^{68}$

\section{PRAVNE POSLJEDICE NEVALJANOSTI UGOVORA I OGRANIČENJE UČINKA NEVALJANOSTI TRAJNOG UGOVORA U HRVATSKOM PRAVU}

U hrvatskom je pravu u odredbama čl. 322.-335. ZOO-a sadržano opće zakonsko uređenje nevaljanosti ugovora, a ono se na odgovarajući način prema odredbi čl. 14. st. 3. ZOO-a primjenjuje na nevaljanost drugih pravnih poslova. Ništetnost ugovora nastupa ex lege čim se pri sklapanju ugovora pojavi neki od razloga ništetnosti, pa je ugovor nevaljan već u trenutku njegova sklapanja, odnosno ex tunc. ${ }^{69}$ Ništetni ugovor ne proizvodi namjeravane pravne učinke, odnosno pravne učinke koje bi on proizvodio da je valjan, što znači da sklapanjem ništetnog ugovora ne nastaje

17. i 20; Oetker, H., Maultzsch, F., loc. cit. u bilj. 64.

66 Busche, J., u: Schubert, C., op. cit., § 142, odl. 17.; Oetker, H., Maultzsch, F., op. cit., str. 353.

67 BGH, XII ZR 67/06 od 6. kolovoza 2008., XII ZR 192/08 od 11. kolovoza 2010. i XII ZR 123/09 od 11. kolovoza 2010. Tako i u odlukama viših zemaljskih sudova (njem. Oberlandesgericht; dalje: OLG) i zemaljskih sudova (njem Landesgericht; dalje: LG): OLG Brandenburg, 3 U 5/03 od 11. studenoga 2009. i OLG Hamburg, 4 U 8/12 od 17. kolovoza 2012., dostupne na: OpenJur, <https://openjur.de/>, 19. siječnja 2019.; LG Hamburg, 316 S 104/10 od 20. rujna 2011., LG Freiburg, 3 S 98/18 od 12. listopada 2018. i KG Berlin, 8 U 223/08 od 28. svibnja 2009., dostupne na: Judicialis Rechtsprechung, <https://www.judicialis.de/>, 19. siječnja 2019. Tako i: Busche, J., u: Schubert, C., op. cit., § 142, odl. 17. i 20.; Dörner, H., u: Schulze, R., op. cit., § 142, odl. 5.; Heinrichs, H., u: Palandt, O., op. cit., str. 154; Oetker, H. i Maultzsch, F., op. cit., str. 352. Suprotno, za ex nunc učinak nevaljanosti ugovora o najmu, vidi: AG Hamburg, 40b C 591/96 od 18. prosinca 1996.; Blank, H., Börstinghaus, U. P., Miete - Das gesamte BGBMietrecht - Kommentar, München, C. H. Beck, 2008., str. 396; Weller, M.-P., Der Mietvertrag als enfant terrible der Privatrechtsdogmatik?, Juristen Zeitung, vol. 67, 18/2012, str. 888.

68 BGH, XII ZR 67/06 od 6. kolovoza 2008.

69 Klarić, P., Vedriš, M., op. cit., str. 137-138; Slakoper, Z., op. cit., str. 314-315. Iz sudske prakse Vrhovnog suda Republike Hrvatske (dalje: VSRH) vidi: Rev 369/10-2 od 18. ožujka 2014., Rev 589/10-2 od 26. listopada 2010., Rev 898/05-2 od 11. travnja 2007., Rev-2257/1997-2 od 18. lipnja 2002. i Rev 514/1996-2 od 17. veljače 2000. Iz sudske prakse županijskih sudova (dalje: ŽS) vidi: ŽS Varaždin, Gž.1428/08-2 od 8. prosinca 2008. i Gž.851/08-2 od 2. lipnja 2008. Sve u radu navedene odluke iz hrvatske sudske prakse, ako nije drukčije izričito naznačeno, dostupne su na: VSRH, Sudska praksa - Portal sudske prakse, <https://sudskapraksa.csp.vsrh. hr>, 19. siječnja 2019. 
vjerovnikovo subjektivno pravo niti dužnikova obveza. Pobojni ugovor je u trenutku njegova sklapanja ex lege valjan, unatoč tome što je u tom trenutku postojao koji od razloga pobojnosti. Pobojni ugovor proizvodi namjeravane pravne učinke, ali se oni mogu poništiti s učinkom ex tunc, od trenutka sklapanja ugovora. ${ }^{70}$

Prevladavajuće je gledište prema kojemu su pobojni ugovori po zakonu valjani sve dok njihovi učinci ne budu poništeni i u austrijskom i u njemačkom pravu, ${ }^{71}$ no ne i u švicarskom. ${ }^{72}$ Razlike između promatranih pravnih poredaka postoje i u pogledu sredstava pobijanja ugovora. Dok se u švicarskom i njemačkom pravu ugovor iz razloga pobojnosti pobija preobražajnim očitovanjem volje, ${ }^{73}$ prema prevladavajućem gledištu u hrvatskom pravu pobojni ugovor pobija se konstitutivnom tužbom i poništava konstitutivnom presudom, ${ }^{74}$ po čemu je hrvatsko pravo blisko rješenjima austrijskog prava. ${ }^{75}$ Odredbe čl. 331. st. 1. i 2. ZOO-a predviđaju mogućnost da se pobijanje ugovora ostvari i izvansudskim putem te otvaraju put tumačenju prema kojemu bi i u hrvatskom pravu bilo moguće ugovor pobijati preobražajnim očitovanjem volje. ${ }^{76}$

Ako se u konkretnom slučaju ispune zakonom predviđene pretpostavke, kao pravne posljedice ništetnosti ugovora te poništenja ugovora zbog nekog od razloga pobojnosti prema odredbama čl. 323. i 332. ZOO-a mogu nastati obveza restitucije i obveza naknade štete, a po tome se hrvatsko pravo načelno ne razlikuje od švicarskog, austrijskog i njemačkog prava. Poredbenopravna stajališta o ograničenju učinka nevaljanosti trajnog ugovora, osim pravnih pitanja u vezi s trenutkom u kojemu nastupa učinak nevaljanosti, tiču se pravnih pitanja u vezi s nastankom obveze restitucije i nastankom obveza prema pravilima o neopravdanom obogaćenju, a ne i pravnih

70 Gorenc, V., op. cit., str. 530-531; Klarić, P., Vedriš, M., op. cit., str. 153; Slakoper, Z., op. cit., str. 331-332; VSRH, Rev-x 126/16-2 od 8. veljače 2017., Rev 1626/15-3 od 18. studenoga 2015., Rev 1040/07-2 od 10. siječnja 2008. i Rev 282/05-2 od 16. studenoga 2005.

71 Za austrijsko pravo, primjerice: Bydlinski, P., op. cit., str. 145. Za njemačko pravo, primjerice: Zerres, T., loc. cit. u bilj. 3 .

72 U švicarskom je pravu u sudskoj praksi BGE-a i dijelu pravne književnosti (primjerice: Gauch, P. et al., op. cit., str. 187) prihvaćena teorija nevaljanosti (njem. Ungültigkeitstheorie) prema kojoj su pobojni ugovori od samog sklapanja nevaljani i ne proizvode namjeravane pravne učinke. Ti učinci nastaju ako strana u čijem je interesu pobojnost ustanovljena naknadno odobri ugovor. U velikome dijelu pravne književnosti (primjerice: Bucher, E., op. cit., str. 210; Schwenzer, I. u: Basler Komm, op. cit., str. 238; Schwenzer, I., op. cit., str. 253) prihvatljivijom se drži teorija pobijanja (njem. Anfechtungstheorie) prema kojoj su pobojni ugovori valjani sve dok ih se ne poništi s učinkom ex tunc. U dijelu pravne književnosti zastupa se i teorija podijeljene nevaljanosti (njem. geteilter Ungültigkeit) prema kojoj je pobojni ugovor za stranu u čijem je interesu pobojnost ustanovljena od sklapanja nevaljan, dok je za drugu stranu on od sklapanja valjan. Bucher, E., op. cit., str. 209-211; Gauch, P. et al., op. cit., str. 187-188; Schwenzer, I., op. cit., str. 252-253; Schwenzer, I. u: Basler Komm, op. cit., str. 237-238.

73 Za švicarsko pravo, primjerice: Schwenzer, I., op. cit., str. 254. Za njemačko pravo, primjerice: Zerres, T., op. cit., str. 68.

74 Crnić, I., op. cit., str. 767; Gorenc, V., op. cit., str. 532-534; Klarić, P., Vedriš, M., op. cit., str. 153; Slakoper, Z., op. cit., str. 332; VSRH, Rev-x 126/16-2 od 8. veljače 2017., Rev 1626/15-3 od 18. studenoga 2015. i Rev 282/05-2 od 16. studenoga 2005.

75 Za austrijsko pravo, primjerice: Bydlinski, P., op. cit., str. 179.

76 Nikšić, S., Pravna sredstva za pobijanje nevaljanih pravnih poslova - ostvarivanje preobražajnog prava ili konstitutivna tužba?, Zbornik Pravnog fakulteta u Zagrebu, vol. 65, 3-4/2015, str. 379385. 
pitanja u vezi s nastankom obveze naknade štete. Stoga se u nastavku analize pravnih posljedica nevaljanosti ugovora podrobnija analiza pitanja odgovornosti za štetu izostavlja, ${ }^{77}$ a prije rasprave o tome je li za hrvatsko pravo prihvatljivo ograničenje učinka nevaljanosti trajnog ugovora pristupa se razmatranju obveze restitucije kao pravne posljedice nevaljanosti ugovora.

\subsection{Obveza restitucije kao pravna posljedica nevaljanosti ugovora}

Okolnost da je jedna strana izvršila kakvu činidbu bez valjanoga pravnog temelja, $\mathrm{u}$ ispunjenju pravno nepostojeće obveze iz ništetnog ugovora ili ugovora koji je poništen zbog nekog od razloga pobojnosti, dovodi do nastanka zakonske obveze restitucije za drugu stranu kojoj je ta činidba izvršena. Strana koja je izvršila kakvu činidbu je vjerovnik obveze restitucije, a strana kojoj je ta činidba izvršena je dužnik obveze restitucije. Zakonska obveza restitucije iz čl. 323. st. 1. ZOO-a, kao i iz čl. 332. st. 1. ZOO-a, obveza je prvenstveno naturalne restitucije, a u slučaju nemogućnosti njezina ispunjenja, ona se preobražava u obvezu novčane restitucije. Obvezu naturalne restitucije i obvezu novčane restitucije prikladno je raspraviti zasebno.

\subsubsection{Obveza naturalne restitucije}

Prema prvom dijelu odredbe čl. 323. st. 1. ZOO-a ${ }^{78}$ u slučaju ništetnosti ugovora svaka ugovorna strana dužna je vratiti drugoj „sve ono što je primila“ na temelju takva ugovora. Izraz „sve ono što je primila“ potrebno je razumjeti kao sve ono što je predmetom svake od činidbi koje su izvršene dužniku obveze restitucije, kakvoga god da su one oblika, a ne samo onog što je on ,primio“ jer je bilo predmetom vjerovnikove izvršene činidbe davanja. Predmetom te činidbe redovito su stvari, a činidba može imati i oblik činjenja, propuštanja i trpljenja. Dužnik obveze restitucije dužan je vjerovniku vratiti sve predmete svake od činidbi koje su mu izvršene, ma kakva god oblika te činidbe bile. $U$ istom je smislu potrebno shvatiti izraz ,nešto bilo ispunjeno" upotrijebljen u prvom dijelu odredbe čl. 332. st. 1. ZOO-a koji glasi „ako je na temelju ugovora koji je poništen nešto bilo ispunjeno, ima se vratiti““ ${ }^{79} \mathrm{U}$ kontekstu te odredbe, „nešto“ što je „bilo ispunjeno“ je sve ono što je „bilo ispunjeno“, odnosno svaki predmet svake od činidbi koje su izvršene dužniku obveze restitucije. ${ }^{80}$ On je dužan vjerovniku vratiti upravo one predmete svake od činidbi koje su mu

77 Slakoper, Z., op. cit., str. 327-328 i 345.

$78 \mathrm{U}$ bitnomu je istovjetno bilo predviđeno i u čl. 104. st. 1. Zakona o obveznim odnosima (NN, br. 53/91., 73/91., 111/93., 3/94., 7/96., 91/96., 112/99. i 88/01.; dalje: ZOO/91), odnosno u čl. 104. st. 1. Zakona o obveznim odnosima iz 1978. godine (Sl. 1. SFRJ, br. 29/78., 39/85. i 57/89.; dalje: ZOO/78).

$79 \mathrm{U}$ bitnome je istovjetno bilo predviđeno i u čl. 113. st. 1. ZOO/91, odnosno u čl. 113. st. 1. $\mathrm{ZOO} / 78$.

80 I u slučaju ništetnosti i u slučaju poništenja ugovora zbog razloga pobojnosti, obveza restitucije je obveza potpune restitucije. Jedina iznimka od pravila potpune restitucije sadržana je u odredbi čl. 333. ZOO-a koja se odnosi na poništenje ugovora zbog ograničene poslovne sposobnosti jednog od ugovaratelja. 
izvršene, te se te obveze ne može osloboditi vraćanjem nečega drugoga. ${ }^{81} \mathrm{U}$ tomu smislu su obveze restitucije iz prvoga dijela odredbi čl. 323. st. 1. i čl. 332. st. 1. ZOO-a obveze naturalne restitucije: vraćaju se in natura upravo oni predmeti svake od ranije izvršenih činidbi.

Za nastanak obveze naturalne restitucije nije relevantno može li se ono što je predmet ranije izvršene činidbe faktično i pravno vratiti vjerovniku obveze naturalne restitucije. Rješenje za slučaj nemogućnosti vraćanja predmeta izvršenih činidbi sadržano je u drugom dijelu odredbe čl. 323. st. 1. ZOO-a, kao i u drugom dijelu odredbe čl. 332. st. 1. ZOO-a. U slučaju nemogućnosti ispunjenja obveze naturalne restitucije zbog toga što je vraćanje predmeta izvršene činidbe nemoguće ili se predmet izvršene činidbe po svojoj prirodi protivi vraćanju, obveza naturalne restitucije se po zakonu preobražava u obvezu novčane restitucije: dužnik je umjesto vraćanja predmeta izvršenih činidbi dužan vjerovniku u novcu nadoknaditi njihovu vrijednost. ${ }^{82}$

Obveza naturalne restitucije nastaje ex lege. ${ }^{83}$ Ona je objektivna posljedica nevaljanosti ugovora, odnosno izvršenja činidbe bez valjanoga pravnog temelja u ispunjenju pravno nepostojeće obveze preuzete nevaljanim ugovorom. Dužnik tu obvezu ima neovisno o svojoj krivnji za nevaljanost ugovora, ali i neovisno o krivnji vjerovnika. Dakle, za obvezu naturalne restitucije nije relevantno tko je, kako i s kakvim subjektivnim stavom izazvao nastanak nekoga od razloga nevaljanosti ugovora. Također, za tu obvezu nije relevantna ni savjesnost, odnosno nesavjesnost dužnika i vjerovnika, ${ }^{84}$ odnosno nije relevantno je li netko od njih znao ili morao znati za postojanje uzroka nevaljanosti ugovora.

Obveza naturalne restitucije iz čl. 323. st. 1. ZOO-a nastaje ex lege u trenutku u kojemu je vjerovnik te obveze izvršio činidbu u ispunjenju svoje nepostojeće obveze preuzete ništetnim ugovorom, ${ }^{85}$ a ne u trenutku sklapanja ništetnog ugovora. ${ }^{86}$

81 Za ispunjenje obveza restitucije iz prvog dijela odredbi čl. 323. st. 1. i čl. 332. st. 2. ZOO-a vrijedi isto što i za ispunjenje svake obveze, pa tako i odredbe čl. 166. st. 1. i 2. ZOO-a. Obveza restitucije ispunjenjem nečega drugog što nije sadržaj te obveze može prestati samo ako se dužnik obveze restitucije o tome sporazumio s vjerovnikom obveze restitucije u smislu odredbe čl. 167. st. 1. ZOO-a o zamjeni ispunjenja.

82 O toj sekundarnoj obvezi novčane restitucije bit će više riječi infra u poglavlju 5.1.2., nakon što se raspravi primarna obveza naturalne restitucije.

83 Tako i: Tumbri, T., Restitucija kao posljedica ništavosti ugovora, Zbornik Pravnog fakulteta u Zagrebu, vol. 46, 5/1996, str. 460 i 469.

84 ibid., str. 462. Usp.: Klarić, P., Vedriš, M., op. cit., str. 650. Vidi i: ŽS Varaždin, Gž.797/07-2 od 15. siječnja 2008.

85 Usp.: Slakoper, Z., op. cit., str. 327; Tumbri, T., op. cit., str. 469. Vidi: VSRH, Rev-x 511/12-2 od 28. travnja 2015. i Rev-x 808/11-2 od 12. rujna 2012.; ŽS Zadar, 13 Gž-1150/18-2 od 9. studenoga 2018.

86 U pojedinim odlukama iz sudske prakse navodi se da je obveza naturalne restitucije dospjela na dan sklapanja ništetnog ugovora, a to je stajalište ispravno samo ako je toga dana i ispunjena ugovorna obveza iz ništetnog ugovora, što je bio slučaj u pojedinim, no ne i u svim predmetima na koje se te odluke odnose. Vidi: VSRH, Rev 1666/11 od 6. svibnja 2015., Rev-x 183/11-2 od 16. listopada 2013. i Rev 141/06-2 od 22. veljače 2006.; Županijski sud u Splitu, Gž-943/20182 od 19. travnja 2018., Gž-281/2017-2 od 1. veljače 2018. i Gž-1565/17-2 od 6. srpnja 2017. Za kritiku stajališta VSRH izraženog u odluci Rev 141/06-2 vidi i: Slakoper, Z., op. cit., str. 327. 
Pogotovo se ne može prihvatiti da bi ta obveza nastajala tek u trenutku pravomoćnosti deklaratorne presude kojom je utvrđena ništetnost ugovora. ${ }^{87}$ Osim toga što je ta obveza nastala u trenutku u kojemu je vjerovnik bez valjanog pravnog temelja izvršio činidbu dužniku te obveze, ona u tom trenutku ujedno i dospijeva. Zastara zahtjeva za naturalnom restitucijom iz čl. 323. st. 1. ZOO-a počinje teći, sukladno odredbi čl. 215. st. 1. ZOO-a, prvog dana poslije dana dospijeća. Budući da je obveza naturalne restitucije objektivna posljedica ništetnosti ugovora, za početak tijeka zastare nije odlučan trenutak vjerovnikovog saznanja za ništetnost ugovora. ${ }^{88}$ Pravo zahtijevati ispunjenje te obveze zastarijeva u općem roku zastare iz odredbe čl. 225. ZOO-a jer zakonom nije određen neki drugi rok zastare. ${ }^{89}$

Pobojni ugovori proizvode namjeravane pravne učinke sve dok oni ne budu poništeni konstitutivnom presudom. ${ }^{90}$ Takvom je presudom stvoreno novo pravno stanje, ali s učinkom ex tunc, od sklapanja pobojnog ugovora. Obveza naturalne restitucije iz čl. 332. st. 1. ZOO-a nastaje kao posljedica toga što je ugovor poništen, a ne toga što je on bio pobojan. Zbog ex tunc učinka poništaja ugovora, ona retroaktivno nastaje u trenutku u kojemu je vjerovnik te obveze izvršio činidbu u ispunjenju svoje, prije poništenja postojeće i valjane, a nakon poništenja pravno nepostojeće obveze preuzete pobojnim ugovorom. Međutim, kako je to novo pravno stanje stvoreno tek konstitutivnom presudom, obveza naturalne restitucije iz čl. 332. st. 1. ZOO-a dospijeva tek u trenutku pravomoćnosti konstitutivne presude kojom je poništen pobojni ugovor. Stoga i opći, petogodišnji rok zastare zahtjeva za naturalnom restitucijom počinje teći prvog dana poslije pravomoćnosti presude kojom je pobojni ugovor poništen, a ne prvog dana poslije dana kojega je vjerovnik izvršio činidbu u ispunjenju obveze iz pobojnog ugovora koji je kasnije poništen.

Ako su obje strane izvršile činidbe u ispunjenju obveza iz nevaljanog ugovora, obveza naturalne restitucije nastaje i za jednu i za drugu stranu, pa se u tom smislu govori i o obostranoj ili dvostranoj restituciji. ${ }^{91} \mathrm{U}$ pravnoj književnosti istaknuto je gledište da je u tom slučaju potrebno analogijom primijeniti odredbu čl. 368. st. 3. ZOO-a, prema kojoj se uzajamna vraćanja nakon raskida ugovora obavljaju prema pravilima o ispunjenju sinalagmatičnih ugovora. ${ }^{92}$ Posljedica je prihvaćanja toga gledišta da bi kod obostrane restitucije do koje dolazi zbog nevaljanosti ugovora na odgovarajući način vrijedilo pravilo istodobnog ispunjenja iz odredbe čl. 358. st. 1. ZOO-a, pa nijedna

87 Tako i: VSRH, Rev-x 183/11-2 od 16. listopada 2013. Suprotno: Tumbri, T., op. cit., str. 465.

88 Tako i: ŽS Zadar, 13 Gž-1150/18-2 od 9. studenoga 2018. Suprotno: Slakoper, Z., op. cit., str. 327.; Tumbri, T., op. cit., str. 464-465.

89 Tako i: Tumbri, T., op. cit., str. 464. Vidi: VSRH, Rev-x 511/12-2 od 28. travnja 2015., Rev-x 183/11-2 od 16. listopada 2013. i Rev-x 808/11-2 od 12. rujna 2012.; ŽS Zadar, 13 Gž-1150/182 od 9. studenoga 2018. U tom je kontekstu prikladno ukazati i na pravno shvaćanje VSRH prema kojemu pokretanjem parničnog postupka za zaštitu kolektivnih interesa potrošača dolazi do prekida zastare pojedinačnih zahtjeva za restituciju, a ona počinje teći ispočetka tek od trenutka pravomoćnosti sudske odluke donesene u povodu kolektivne tužbe za zaštitu prava i interesa (VSRH, Rev-2245/17 od 20. ožujka 2018.).

90 Tako i: VSRH, Rev-x 126/16-2 od 8. veljače 2017., Rev 1626/15-3 od 18. studenoga 2015. i Rev 282/05-2 od 16. studenoga 2005.

91 Usp.: Slakoper, Z., u: Slakoper, Z. et al., op. cit., str. 327; Tumbri, T., op. cit., str. 461.

92 Slakoper, Z., op. cit., str. 327. Usp. i: Gorenc, V., op. cit., str. 535. 
strana ne bi bila dužna ispuniti obvezu naturalne restitucije ako druga strana ne bi bila spremna istodobno ispuniti svoju obvezu. To se stajalište ne može prihvatiti u pogledu obveze naturalne restitucije iz čl. 323. st. 1. ZOO-a, a u pogledu obveze naturalne restitucije iz čl. 332. st. 1. ZOO-a ne može se prihvatiti olako. Naime, kod raskida ugovora je riječ o tome da ugovorni odnos, koji je bio zasnovan valjanim ugovorom, raskidom ne prestaje u potpunosti, već se preobražava u likvidacijski odnos u kojemu ugovorne strane terete likvidacijske obveze vraćanja onoga što je ispunjeno prije raskida, a ti su zahtjevi za vraćanjem po svojoj pravnoj prirodi ugovorni zahtjevi, ${ }^{93}$ pa je opravdana primjena pravila o ispunjenju sinalagmatičnih ugovora. Nasuprot tomu, ništetni ugovori ne proizvode namjeravane pravne učinke, a pobojni ugovori su valjani dok se njihovi učinci ne ponište ex tunc konstitutivnom presudom kojom se uspostavlja novo pravno stanje, pa obvezni odnos između strana ništetnog ugovora i poništenog pobojnog ugovora, prema ZOO-u de lege lata, nije ugovorni odnos koji bi se preobrazio u likvidacijski odnos, već je zakonski, izvanugovorni obvezni odnos, pa ovdje ne bi bilo mjesta primjeni analogijom pravila o učincima sinalagmatičnih ugovora. ${ }^{94}$

Ratio zakonske obveze naturalne restitucije jest uspostava stanja kakvo je ono bilo prije negoli je vjerovnik te obveze izvršio neku činidbu bez pravnog temelja $\mathrm{u}$ ispunjenju pravno nepostojeće obveze preuzete nevaljanim ugovorom. Institut naturalne restitucije po svojoj svrsi pokazuje izvjesne sličnosti s institutom odgovornosti za štetu i institutom neopravdanog obogaćenja, ali se nikako ne bi smio poistovjetiti s nekim od njih. Naime, to što je vjerovnik obveze naturalne restitucije izvršio kakvu činidbu bez pravnog temelja ne znači nužno i da se njegova imovina umanjila, odnosno da je on pretrpio stvarnu štetu zbog nevaljanosti ugovora. Šteta koju je on pretrpio naknađuje se prema posebnim pretpostavkama odgovornosti za štetu iz čl. 323. st. 2. i čl. 332. st. 2. ZOO-a, a ne naturalnom restitucijom iz čl. 323. st. 1. i čl. 332. st. 1. ZOO-a. Vjerovnik ne ostvaruje svoje pravo na restituciju zahtjevom za naknadom štete, već zahtjevom za vraćanjem predmeta izvršenih činidbi. ${ }^{95}$ Također, to što je vjerovnik obveze naturalne restitucije izvršio kakvu činidbu bez pravnog temelja ne znači nužno i da se time imovina dužnika te obveze povećala, što je pretpostavka za primjenu instituta neopravdanog obogaćenja, odnosno stjecanja bez osnove kako se taj institut naziva u hrvatskom pravu. Obveze naturalne restitucije iz čl. 323. st. 1. i čl. 332. st. 1. ZOO-a nisu isto što i obveza vraćanja stečenog bez

93 Miladin, P., op. cit., str. 1094; Tot, I., Prestanak, str. 1173. i 1176.

94 U poredbenoj su pravnoj književnosti zastupljena i stajališta prema kojima se teorija preobrazbe (njem. Umwandlungstheorie), prema kojoj ugovorni odnos nakon raskida ne prestaje nego se preobražava u likvidacijski odnos, proteže i na obvezni odnos strana nakon pobijanja ugovora zbog razloga pobojnosti, pa se drži da je i zahtjev za vraćanjem onoga što je ispunjeno na temelju pobojnoga ugovora ugovorni zahtjev. Za švicarsko pravo, vidi: Wiegand, W., op. cit., str. 717-722. Vidi i napomene infra u bilj. 125.

95 U pravnoj je književnosti zastupljeno gledište prema kojemu je tužba za naknadu štete jedno od mogućih pravnih sredstava za ostvarenje zahtjeva za naturalnom restitucijom: Tumbri, T., op. cit., str. 464. Vjerovnik obveze naturalne restitucije svoje pravo ostvaruje zahtjevom za naturalnom restitucijom. Ako je zbog nevaljanosti ugovora pretrpio kakvu štetu, onda uz zahtjev za naturalnom restitucijom, svoje pravo na naknadu štete ostvaruje zahtjevom za naknadom štete. 
osnove iz čl. 1111. st. 1. ZOO-a, a zahtjev za naturalnom restitucijom nije kondikcijski zahtjev. ${ }^{96}$ Vjerovnik uz zahtjev za naturalnom restitucijom može prema dužniku isticati i kondikcijske zahtjeve, za što je pretpostavka da je vjerovnikovim izvršenjem činidbe dužnik doista i nešto bez osnove stekao, no to što je vjerovnik izvršio činidbu bez pravnog temelja ne znači nužno da je dužnik predmet te činidbe doista i stekao.

Naime, u hrvatskom je pravu stjecanje prava vlasništva na temelju pravnog posla, istovjetno kao i u švicarskom i austrijskom, a za razliku od njemačkog prava, uređeno na načelu kauzalne tradicije. ${ }^{97}$ Ako predaja stvari nije posljedica valjanoga pravnog posla usmjerenog na stjecanje prava vlasništva, njome ne prelazi pravo vlasništva na osobu koja je stvar primila. Time što je vjerovnik obveze naturalne restitucije $u$ ispunjenju svoje pravno nepostojeće obveze preuzete nevaljanim ugovorom predao svoju stvar drugome u posjed, drugi nije postao vlasnikom te stvari i stvar nije prešla u njegovu imovinu u smislu odredbe čl. 1111. st. 1. ZOO-a. Stvar je ostala $\mathrm{u}$ imovini vjerovnika te je on i dalje njezin vlasnik. On za vraćanje te stvari u svoj neposredan posjed na raspolaganju ima dva različita zahtjeva: obveznopravni zahtjev za naturalnom restitucijom te vlasnički zahtjev. Stoga on svoje pravo na naturalnu restituciju može ostvarivati i vindikacijom koja mu je pogodnije pravno sredstvo jer vlasnički zahtjev za povratom stvari ne zastarijeva. ${ }^{98}$ Kako nije riječ o stjecanju bez osnove, tako on nema kondikcijski zahtjev za vraćanjem stvari u posjed, a i inače: „gdje ima mjesta vindikaciji nema mjesta kondikciji, i obrnuto". 99

Jednako tako, ako nevaljani ugovor nije bio usmjeren na prijenos prava vlasništva na predanoj stvari, već na privremeni prijenos stvari radi uporabe ili korištenja, predajom stvari u neposredan posjed dužniku obveze naturalne restitucije nije na njega prešlo pravo vlasništva te stvari, a predajom stvari u njegov posjed nije se povećala i njegova imovina za njezinu vrijednost. Stoga ni ovdje ne može biti riječ o stjecanju bez osnove iz čl. 1111. st. 1. ZOO-a. Tako se, primjerice, zakupnikova imovina ne bi povećala samom predajom zakupljene stvari u njegov posjed za vrijednost te stvari ni kad bi ugovor o zakupu bio valjan, pa on zakupljenu stvar ne stječe bez osnove ni kada

96 U pravnoj književnosti i sudskoj praksi zahtjevi za naturalnom restitucijom iz čl. 323. st. 1. i čl. 332. st. 1. ZOO-a redovito se poistovjećuju s kondikcijskim zahtjevom za vraćanjem stečenog bez osnove iz čl. 1111. st. 1. ZOO, pa tako i: Gorenc, V., op. cit., str. 535; Klarić, P., Vedriš, M., op. cit., str. 649-650; Tumbri, T., op. cit., str. 464; VSRH, Rev-x 511/12-2 od 28. travnja 2015., Rev-x 183/11-2 od 16. listopada 2013. i Rev-x 808/11-2 od 12. rujna 2012.; ŽS Zadar, 13 Gž1150/18-2 od 9. studenoga 2018.

97 Gavella, N. u: Gavella, N. (red.), Stvarno pravo, Zagreb, Informator, 1998., str. 325-326 i 426427. Vidi i: Nikšić, S., Imovina u građanskom pravu, Zbornik Pravnog fakulteta u Zagrebu, vol. 62, br. 5-6/2012, str. 1627-1628.

98 Prema odredbi čl. 161. st. 2. Zakona o vlasništvu i drugim stvarnim pravima, NN, br. 91/96., 68/98., 137/99., 22/00., 73/00., 129/00., 114/01., 79/06., 141/06., 146/08., 38/09., 153/09., 143/12. i 152/14. (dalje: ZV).

99 Gavella, N., op. cit., str. 427. Kondikciji će biti mjesta, a vindikaciji neće, ako je vlasnik stvari to prestao jer je druga osoba originarno, na temelju zakona stekla pravo vlasništva na toj stvari. O međusobnom isključivanju vindikacije i kondikcije, posebno vidi i: Miladin, P., Odnos, str. 1084-1086, 1089 i 1093; Miladin, P., Problem vraćanja poduzeća stečenog na temelju ništavog ugovora o kupoprodaji poduzeća, Zbornik Pravnog fakulteta u Zagrebu, vol. 61, 2/2011, str. 754; Miladin, P., Markovinović, H., op. cit., str. 11. Vidi i: Held, H.-R., Neki problemi suvremenog uređenja stjecanja bez osnove, Hrvatska pravna revija, vol. 15, 12/2015, str. 16. 
je ugovor o zakupu nevaljan. Zakupodavčev zahtjev za vraćanjem stvari u njegov neposredan posjed zbog nevaljanosti ugovora o zakupu obveznopravni je zahtjev za naturalnom restitucijom iz čl. 323. st. 1. ili čl. 332. st. 1. ZOO-a, a ne kondikcijski zahtjev za vraćanjem stečenog bez osnove iz čl. 1111. st. 1.ZOO-a. Ako je zakupodavac vlasnik, onda mu uz obveznopravni zahtjev stoji na raspolaganju i vlasnički zahtjev iz čl. 161. st. 1. ZV-a. Nevlasniku stvari, primjerice podzakupodavcu, za vraćanje stvari predane na temelju nevaljanog ugovora, primjerice ugovora o podzakupu, na raspolaganju stoji samo obveznopravni zahtjev za naturalnom restitucijom iz čl. 323. st. 1. ili čl. 332. st. 1. ZOO-a.

Vjerovnik obveze naturalne restitucije koji je u ispunjenju svoje pravno nepostojeće obveze iz nevaljanog ugovora izvršio dužniku novčanu činidbu u pravilu se neće moći poslužiti reivindikacijom jer se vraćanje generičnih stvari, uključujući i gotov novac, prema čl. 162. st. 2. ZV-a može njome zahtijevati, samo ako su one individualizirane u mjeri da se mogu opisati osobine po kojima se one razlikuju od drugih istovrsnih stvari, ${ }^{100}$ a i inače se pravo vlasništva ne može imati na količini stvari istoga roda pa tako ni na nekoj novčanoj svoti. ${ }^{101}$ Gotov novac ne daje se in specie ni onda kada je predmet valjane obveze novčana činidba na predaju gotova novca. $\mathrm{K}$ tome, $\mathrm{u}$ suvremenomu pravnom prometu predmet novčane činidbe redovito nije gotov novac, već je to novčana tražbina. Prijenos tražbine u hrvatskom pravu valjan je i u slučaju nevaljanosti osnovnoga pravnog posla koji je podloga toga prijenosa. ${ }^{102}$ Ako je jedna strana u ispunjenju nepostojeće obveze iz nevaljanog ugovora izvršila drugoj novčanu činidbu, time će doći do povećanja imovine druge strane, a kako za to povećanje nije postojao valjani pravni temelj, druga će se strana za primljeni iznos novca neopravdano obogatiti, odnosno taj će iznos novca steći bez osnove. Kako je riječ o generičkim stvarima i pravima, ovdje u pravilu otpada zahtjev za naturalnom restitucijom iz čl. 323. st. 1. ili čl. 332. st. 1. ZOO-a, no vjerovnik ima kondikcijski zahtjev za vraćanjem stečenoga bez osnove iz čl. 1111. st. 1. ZOO-a.

Analiza objavljenih odluka iz sudske prakse u vezi s odredbom čl. 323. st. 1. ZOO-a, odnosno odredbom čl. 104. st. 1. ZOO/91, pokazuje da se veliki broj tih odluka odnosi na pitanje vraćanje gotova novca predanog u stranoj valuti kao valuti ispunjenja na temelju ugovora o zajmu koji je bio ništetan zbog protivnosti prisilnim propisima o deviznom poslovanju. Prema ustaljenom stajalištu VSRH-a, dužnik obveze naturalne restitucije obvezan je vratiti primljeni iznos novca upravo u stranoj valuti, a ne kunsku protuvrijednost primljenog iznosa. ${ }^{103}$ Pravna književnost suglasna

100 Gavella, N., op. cit., str. 434. Usp.: Miladin, P., Odnos, str. 1090; Miladin, P., Markovinović, H., op. cit., str. 11.

101 Gavella, N., op. cit., str. 50 i 434-435; Slakoper, Z., Ugovor o zajmu, u: Slakoper, Z. (red.), Bukovac Puvača, M., Mihelčić, G. (ur.), Bankovni i financijski ugovori, Zagreb, Narodne novine, 2017., str. 531-532.

102 Vidi, osobito: Markovinović, H., Ugovor o cesiji, doktorska disertacija, Zagreb, Pravni fakultet Sveučilišta u Zagrebu, 2005., str. 52.

103 VSRH, Rev-x 93/15-2 od 16. prosinca 2015., Rev 2781/11-2 od 16. lipnja 2015., Rev 1809/112 od 10. veljače 2015., Rev 247/11-3 od 22. listopada 2014., Rev 2398/10-2 od 15. listopada 2014., Rev 965/09-2 od 7. listopada 2014., Rev-x 633/10-2 od 1. listopada 2014., Rev-x 474/10-2 od 21. svibnja 2013., Rev 933/09-2 od 23. travnja 2014., Rev-x 529/13-2 od 25. ožujka 2014., Rev 199/10-2 od 15. rujna 2011., Rev 729/06-2 od 29. studenoga 2007., Rev 
je s tim stajalištem s obrazloženjem da bi vraćanjem kunske protuvrijednosti protivno deviznim propisima faktično bio omogućen prijenos strane valute koja bi ostala dužniku obveze naturalne restitucije. ${ }^{104}$

\subsubsection{Obveza novčane restitucije}

Umjesto obveze naturalne restitucije iz prvog dijela odredaba čl. 323. st. 1. i čl. 332. st. 1.ZOO-a, prema drugom dijelu tih odredbi u dva će slučaja nevaljanost ugovora za posljedicu imati obvezu plaćanja „odgovarajuće novčane naknade“: (i) ako vraćanje nije moguće, te (ii) ako se narav onoga što je ispunjeno protivi vraćanju. Ovdje je riječ o tome da se obveza naturalne restitucije, zbog nemogućnosti njezina ispunjenja, ex lege preobražava u obvezu novčane restitucije. Vjerovnik obveze novčane restitucije ima obveznopravni zahtjev za vraćanjem novčane vrijednosti predmeta činidbi koje je izvršio u ispunjenju svoje pravno nepostojeće obveze iz nevaljanog ugovora, a taj je zahtjev funkcionalno istorodan, ali sekundaran u odnosu na primarni zahtjev za naturalnom restitucijom. ${ }^{105}$ „Odgovarajuća novčana naknada“ nije naknada štete, već je nadoknada vrijednosti predmeta izvršenih činidbi čije vraćanje nije moguće te je u tom pogledu ona samo nadomjestak ekvivalentan vraćanju predmeta izvršenih činidbi in natura. ${ }^{106}$

Ovdje nije riječ ni o naknadi vrijednosti postignute koristi u smislu čl. 1111. st. 1. ZOO-a. ${ }^{107}$ Obvezama novčane restitucije iz čl. 323. st. 1. i čl. 332. st. 1. ZOO-a vraća se vrijednost predmeta ranije izvršenih činidbi, a obvezom iz čl. 1111. st. 1. ZOO-a vraća se vrijednost koristi koju je dužnik obveze restitucije kao kondikcijski dužnik imao od njemu izvršenih činidbi. Naime, to što je vjerovnik obveze restitucije izvršio kakvu činidbu bez valjanoga pravnog temelja ne znači nužno da se time dužnik te obveze obogatio, odnosno da se time povećala njegova imovina. To je neprijeporna pretpostavka primjene instituta stjecanja bez osnove iz čl. 1111. st. 1. ZOO-a, neovisno o prijeporima u pravnoj književnosti glede ostalih pretpostavaka nastanka stjecanja bez osnove. ${ }^{108}$ Zbog uređenja stjecanja prava vlasništva na temelju

299/07-2 od 18. travnja 2007., Rev 1347/01-2 od 5. listopada 2005., Rev 392/04-2 od 6. travnja 2005., Rev 853/02-2 od 15. rujna 2004., Rev 2579/00-2 od 17. ožujka 2004., Rev 1239/01-2 od 19. studenoga 2003., Rev 531/00-2 od 10. rujna 2003., Rev-1509/00-2 od 27. kolovoza 2003., Rev-188/02-2 od 22. srpnja 2003., Rev 3158/1999-2 od 16. srpnja 2003. i Rev-746/00-2 od 9. srpnja 2003.

104 Slakoper, Z., op. cit., str. 537.

105 Usp.: Miladin, P., Problem, str. 761.

106 Usp.: ibid., str. 774; Miladin, P., Odnos, str. 1094.

107 Suprotno, u pravnoj se književnosti ističe da je vraćanje novčanog nadomjestka uređeno pravilima o neopravdanom obogaćenju pa da je u tom smislu obveza novčane restitucije iz čl. 323. st. 1. ZOO-a istorodna s obvezom vraćanja postignute koristi iz čl. 1111. st. 1. ZOO-a: ibid. Također se ističe da se u slučaju novčane restitucije radi o stjecanju bez osnove, ali da se na nju ne primjenjuje opće pravilo o stjecanju bez osnove iz čl. 210. ZOO/91 (danas čl. 1111. ZOO), već posebno pravilo iz čl. 104. st. 1. ZOO/91 (danas čl. 323. st. 1. ZOO-a): Tumbri, T., op. cit., str. 463.

108 Prijepori se odnose na pretpostavku umanjenja imovine na strani kondikcijskog vjerovnika. Prema većinskom stajalištu pravne književnosti, osim povećanja imovine na strani kondikcijskog dužnika, jedna je od pretpostavki nastanka obveznog odnosa stjecanja bez osnove umanjenje 
pravnog posla na načelu kauzalne tradicije, ako je na temelju nevaljanog ugovora usmjerenog na prijenos prava vlasništva jedna strana predala drugoj neku stvar, druga time nije postala vlasnikom te stvari, ta stvar nije prešla u njezinu imovinu i ona se za tu stvar nije obogatila. Kako je ugovor nevaljan, tako je ona tu stvar obvezna vratiti prvoj strani, odnosno naknaditi joj njezinu vrijednost ako njezino vraćanje više nije moguće. Osim obveznopravnog zahtjeva za novčanom restitucijom, odnosno nadoknadom vrijednosti predmeta činidbe izvršene bez pravnog temelja, vjerovniku obveze restitucije na raspolaganju je i kondikcijski zahtjev za vraćanjem koristi koje je dužnik imao od njemu izvršene činidbe, ali obveznopravni zahtjev za novčanom restitucijom nije kondikcijski zahtjev za vraćanjem postignute koristi niti za vraćanjem vrijednosti postignute koristi. ${ }^{109}$

Budući da je u čl. 323. st. 1. i čl. 332. st. 1. ZOO-a riječ o preobrazbi obveze naturalne restitucije ex lege u obvezu novčane restitucije, u pogledu nastanka obveze, irelevantnosti krivnje, savjesnosti i nesavjesnosti obje strane te zastare zahtjeva za restituciju vrijedi istovjetno što i za obvezu naturalne restitucije. ${ }^{110}$ Prema odredbama čl. 323. st. 1. i čl. 332. st. 1. ZOO-a, ekvivalentnost novčane i naturalne restitucije, odnosno odmjeravanje novčane vrijednosti predmeta izvršene činidbe čije vraćanje in natura nije moguće, ravna se „prema cijenama u vrijeme donošenja sudske odluke“.

imovine na strani kondikcijskog vjerovnika: Crnić, I., op. cit., str. 1991; Gorenc, V., op. cit., str. 1866; Klarić, P., Vedriš, M., op. cit., str. 646. Prema suprotnom stajalištu, jedna je od pretpostavki nastanka toga obveznog odnosa obogaćenje na strani kondikcijskog dužnika, do kojeg može doći povećanjem njegove imovine i uštedom, odnosno neumanjenjem njegove imovine, ali pretpostavka nije i umanjenje imovine na strani kondikcijskog vjerovnika: Miladin, P., Odnos, str. 1098-1101; Miladin, P., Markovinović, H., op. cit., str. 8-10 i 16-17.

109 Analiza odluka iz sudske prakse pokazuje da se obveze naturalne restitucije i njima podredne obveze novčane restitucije iz čl. 323. st. 1. i čl. 332. st. 1. ZOO-a često pogrešno poistovjećuju s obvezama naknade štete iz čl. 323. st. 2. i čl. 332. st. 2. ZOO-a te s obvezom vraćanja postignute koristi iz čl. 1111. st. 1. ZOO-a. Tako, primjerice, i u: ŽS Varaždin, 24 Gž-777/15-3 od 25. travnja 2017. U tom se predmetu radilo o protutužbenom zahtjevu prodavatelja za isplatom naknade za korištenje motornog vozila za razdoblje u kojem je ono nakon sklapanja ništetnog ugovora o kupoprodaji bilo u posjedu kupca. Sud je, unatoč utvrđenju da je vozilo bilo vraćeno prodavatelju, o protutužbenom zahtjevu odlučivao primjenom dijela odredbe čl. 323. st. 1. ZOO-a o obvezi novčane restitucije. Primjeni te odredbe nije bilo mjesta jer je vraćanjem vozila prodavatelju otpao njegov zahtjev za naturalnom restitucijom, a time i podredni zahtjev za novčanom restitucijom. Primjena te odredbe bila bi opravdana da vraćanje vozila nije bilo moguće pa da je zbog toga protutužitelj ustao zahtjevom za nadoknadom vrijednosti vozila. Protutužbeni je zahtjev u tom predmetu bio kondikcijski zahtjev za vraćanjem koristi koju je protutuženik postignuo time što je vozilo bez valjanoga pravnog temelja bilo kroz izvjesno vrijeme u njegovom posjedu. Protutuženik se korištenjem vozila neopravdano obogatio uštedom, bez osnove je stekao korist u visini iznosa koje bi on inače bio morao platiti za korištenje vozila na valjanom pravnom temelju. Međutim, sud je iznos naknade za korištenje utvrdio kao iznos smanjenja vrijednosti vozila za vrijeme dok se ono nalazilo u posjedu protutuženika te je taj iznos dosudio protutužitelju. Time je sud odlučujući o kondikcijskom zahtjevu iz čl. 1111. st. 1. ZOO-a, a pogrešno primjenjujući odredbe čl. 323. st. 1. ZOO-a o obvezi novčane restitucije, zapravo nadoknadio štetu koju je protutužitelj pretrpio zbog ništetnosti ugovora, što od suda protutužbenim zahtjevom nije traženo, a pritom je o tome odlučio, a da nije ispitao postoje li pretpostavke odgovornosti za štetu iz čl. 323. st. 2. ZOO-a.

110 Vidi supra u poglavlju 5.1.1. 
Pod „sudskom odlukom“ potrebno je razumjeti odluku kojom se odlučuje o zahtjevu za novčanom restitucijom, a ne odluku kojom je ugovor utvrđen ništetnim ${ }^{111}$ ili je konstitutivno poništen.

Do preobrazbe obveze naturalne restitucije u obvezu novčane restitucije doći će, prema odredbama čl. 323. st. 1. i čl. 332. st. 1. ZOO-a, ako „vraćanje nije moguće“. Ako je vjerovnik obveze naturalne restitucije izvršio dužniku činidbu davanja koja za predmet ima stvar, ispunjenje te obveze bit će nemoguće ako je species potrošen ili je propao. ${ }^{112}$ Ono će biti nemoguće i ako je dužnik tu stvar otuđio, a treći je u dobroj vjeri stekao, ${ }^{113}$ i ako je dužnik predmet njemu izvršene činidbe korjenito preinačio, ${ }^{114} \mathrm{i}$ ako je stvar koja je predmet izvršene činidbe prirasla drugoj stvari. ${ }^{115}$

Do preobrazbe obveze naturalne restitucije u obvezu novčane restitucije doći će, prema odredbama čl. 323. st. 1. i čl. 332. st. 1. ZOO-a, i ako se ,narav onoga što je ispunjeno protivi vraćanju“. Prema jednom od dva moguća tumačenja toga dijela tih odredbi, koja se međusobno nužno ne isključuju, riječ je o tome da je vraćanje predmeta izvršene činidbe načelno moguće, ali se predmet izvršene činidbe po svojoj prirodi protivi vraćanju. U pravnoj je književnosti argumentirano, primjerice, pod kojim se okolnostima poduzeće preneseno temeljem nevaljanog ugovora po svojoj pravnoj prirodi protivi vraćanju. ${ }^{116}$ Ako je ugovor ništetan zbog toga što je predmet izvršene činidbe nedopušten, iako je vraćanje faktički moguće, ne bi se mogao usvojiti zahtjev za naturalnom restitucijom onoga što je protivno Ustavu Republike Hrvatske, prisilnim propisima ili moralu društva, ${ }^{117}$ no u tom slučaju nema mjesta ni novčanoj restituciji.

Drugo od mogućih tumačenja je da se obveza naturalne restitucije preobražava u obvezu novčane restitucije ako je vjerovnik obveze naturalne restitucije izvršio činidbu koja je takvog oblika da se predmet izvršene činidbe po svojoj prirodi protivi vraćanju. To su s jedne strane slučajevi u kojima je vjerovnik izvršio činidbu koja je po svojem obliku činidba činjenja koja za predmet ima rad, i to funkciju rada, a ne rezultat rada. S druge strane to su slučajevi u kojima je izvršena činidba koja je po svojem obliku činidba propuštanja ili činidba trpljenja. Upravo su činidbe ovih oblika one koje se redovito javljaju kao trajne činidbe u trajnim obveznim odnosima. Trajna je činidba ona koju je dužnik na temelju obveznopravnog odnosa dužan neprekidno, kontinuirano izvršavati. Obveza koja za predmet ima trajnu činidbu ne može prestati ispunjenjem jer je u njezinoj prirodi da se ona kontinuirano izvršava kroz izvjesno

111 Tako i: ŽS Zadar, 13 Gž-1150/18-2 od 9. studenoga 2018.

112 Usp.: Gorenc, V., op. cit., str 520; Klarić, P., Vedriš, M., op. cit., str. 151; Miladin, P., Problem, str. 749 i 762; Slakoper, Z., op. cit., str. 327; Tumbri, T., op. cit., str. 463.

113 Usp.: Miladin, P., Problem, str. 765; Tumbri, T., op. cit., str. 463. Vidi: ŽS Varaždin, Gž.797/072 od 15. siječnja 2008.; ŽS Zadar, 13 Gž-1150/18-2 od 9. studenoga 2018..

114 Vidi, u kontekstu vraćanja poduzeća stečenog bez osnove: Miladin, P., Problem, str. 770-771.

115 U pravnoj se književnosti ističe da bi se u tom slučaju radilo o nesvrhovitosti vraćanja, odnosno o tome da se zbog nerazmjerno velikih troškova rastavljanja narav ispunjenog protivi vraćanju, a kao primjer se navodi ugradnja tuđe opeke u zid i sl.: Gorenc, V., str. 520.; Slakoper, Z., op. cit., str. 327.

116 Miladin, P., Problem, str. 754-755 i 770.

117 Usp.: Radolović, A., op. cit., str. 121. 
vrijeme, pa ona prestaje tek prestankom trajnog obveznog odnosa. ${ }^{118}$ Tako je trajna činidba predmet trajne obveze u trajnim obveznim odnosima koji se zasnivaju pojedinim tipovima trajnih ugovora s činidbom činjenja koja za predmet ima funkciju rada, a takvi su, primjerice, ugovor o radu, ugovor o ostavi, ugovor o uskladištenju, ugovor o službi i ugovor o skrbi o tuđem poslu ako on ima obilježja ugovora o službi. ${ }^{119}$ Ugovori o privremenom prepuštanju predmeta ugovora najmanje na uporabu su trajni ugovori kojima se zasnivaju trajni obvezni odnosi u kojima je karakteristična trajna obveza prepuštanja uporabe, odnosno ostavljanja na uporabu, a predmet je te trajne obveze trajna činidba koja ima oblik trpljenja. ${ }^{120} \mathrm{U}$ tu se skupinu trajnih ugovora ubrajaju, primjerice, ugovor o najmu, ugovor o zakupu, ugovor o leasingu, ugovor o licenciji, ugovor o posudbi, ugovor o zajmu i ugovor of franchisingu. ${ }^{121}$

Trajne činidbe koje imaju oblik činidbe činjenja s funkcijom rada kao predmetom činidbe, oblik trpljenja ili oblik propuštanja se po svojoj prirodi protive vraćanju, a često njihovo vraćanje nije ni moguće, no njihovu vrijednost u pravilu će biti moguće izraziti novčanim ekvivalentom. Upravo na ove činidbe smjeraju odredbe čl. 323. st. 1. i čl. 332. st. 1. ZOO-a kada govore o obvezi novčane restitucije ako se „narav onoga što je ispunjeno protivi vraćanju“. U prilog tomu gledištu govori i povijesno tumačenje tih odredaba ZOO-a. One su istovjetne odredbama čl. 104. st. 1.i čl. 113. st. 1. ZOO/78, a te odredbe $\mathrm{ZOO} / 78$, kao većina drugih, svoj izvor imaju u, tzv. Konstantinovićevoj skici. ${ }^{122}$ Naime, čl. 85. st. 1. Konstantinovićeve skice odnosi se na obvezu naturalne restitucije. ${ }^{123}$ U čl. 85. st. 2. sadržana je odredba koja glasi: „U slučaju ugovora čije se izvršenje proteže kroz izvesno vreme, kao što je ugovor o zakupu, ili ugovor o radu, ili ugovor u udruženju, ako se priroda onog što je ispunjeno protivi povraćaju, druga strana dužna je dati odgovarajuću naknadu u novcu." ${ }^{24}$ Obvezu je novčane restitucije, dakle, Konstantinović predvidio kao ekvivalent obvezi naturalne restitucije upravo u slučaju nevaljanosti trajnih ugovora, odnosno za slučaj nemogućnosti ispunjenja obveze naturalne restitucije $\mathrm{u}$ vezi $\mathrm{s}$ izvršenim činidbama iz nevaljanih trajnih ugovora, koje se po svojoj prirodi protive vraćanju, a to su one činidbe koje imaju prirodu trajne činidbe i oblik činidbe rada, trpljenja ili propuštanja. ${ }^{125}$

118 Tot, I., Pojam, str. 60.

119 ibid., str. 65.

120 ibid., str. 64.

121 ibid., str. 64-65.

122 Konstantinović, M., Obligacije i ugovori - Skica za Zakonik o obligacijama i ugovorima, Beograd, Pravni fakultet u Beogradu, 1969.

123 Čl. 85. st. 1. Konstantinovićeve skice glasi: „Ako je na osnovu apsolutno ništavog ili poništenog ugovora nešto bilo ispunjeno, ima se izvršiti povraćaj“.

124 ibid., str. 37.

125 Bitno je napomenuti i da čl. 85. Konstantinovićeve skice nikako ne upućuju na primjenu pravila instituta stjecanja bez osnove, koji se naziva „neosnovanim obogaćenjem“, a čije uređenje započinje općim pravilom, sadržanim u čl. 168. st. 1., po kojemu se nitko ne može obogatiti bez osnove na tuđi račun (ibid., str. 60). Štoviše, u pogledu obostrane restitucije čl. 85. st. 3. upućuje na pravila o ispunjenju sinalagmatičnih ugovora: „Povraćaj uzajamnih davanja vrši se po pravilima za izvršenje dvostranih ugovora.“ (Ibid., str. 37.). Ovo upućivanje ukazuje da bi po Konstantinovićevoj koncepciji nevaljanosti ugovora zahtjevi za restitucijom mogli biti ugovorni zahtjevi, a obvezni odnos između strana nevaljanog ugovora mogao biti shvaćen 
Stoga, primjerice, u slučaju nevaljanosti ugovora o službi, koji u hrvatskom pravu nije zakonom uređen kao poseban tip ugovora i koji je trajni ugovor kojim se zasniva trajni obvezni odnos s karakterističnom trajnom obvezom koja za predmet ima činidbu rada, služboprimac ne bi mogao zahtijevati naturalnu restituciju iz prvog dijela odredbi čl. 323. st. 1. i čl. 332. st. 1. ZOO-a, jer vraćanje izvjesno vrijeme obavljanog posla nije moguće in natura, ali bi mogao zahtijevati novčanu restituciju iz drugog dijela odredbi čl. 323. st. 1 . i čl. 332. st. 1. ZOO-a. ${ }^{126}$

U ugovorima o prepuštanju stvari na uporabu, kakav je primjerice ugovor o najmu, osim obveze predaje stvari u posjed koju najmodavac ispunjava jednokratnom činidbom davanja stvari, on ima i trajnu obvezu prepuštanja stvari na uporabu koja za predmet ima trajnu činidbu koja je po svojem obliku činidba trpljenja. ${ }^{127}$ Ako je ugovor o najmu nevaljan, najmodavac ima zahtjev za naturalnom restitucijom iz prvog dijela odredbi čl. 323. st. 1. i čl. 332. st. 1. ZOO-a radi vraćanja stvari u svoj neposredni posjed, ali i zahtjev za novčanom restitucijom iz drugog dijela odredbi čl. 323. st. 1. i čl. 332. st. 1. ZOO-a radi nadoknade vrijednosti izvršene činidbe čije vraćanje nije moguće naturalnom restitucijom, a to je činidba trpljenja najmoprimčeve uporabe stvari kroz vrijeme dok se stvar nalazila u njegovom posjedu. O tom bi zahtjevu za novčanom restitucijom u slučaju spora sud trebao odlučiti, u skladu s odredbama čl. 323. st. 1. i čl. 332. st. 1. ZOO-a, ,prema cijenama u vrijeme donošenja sudske odluke“. Međutim, činidba trpljenja uporabe redovito nema tržišnu vrijednost. Naime, zahtjev za novčanom restitucijom najmodavčeve izvršene činidbe trpljenja uporabe nije isto što i kondikcijski zahtjev za naknadom koristi koje je najmoprimac imao od uporabe te stvari bez pravnoga temelja. Najmodavac ima i taj kondikcijski zahtjev prema najmoprimcu prema čl. 1111. st. 1. ZOO-a, ${ }^{128}$ a iznos toga zahtjeva moguće je izračunati prema tržišnoj najamnini. ${ }^{129}$ Najmoprimac s druge strane ima

ne kao zakonski obvezni odnos, već kao ugovorni odnos koji se preobrazio u likvidacijski odnos (vidi supra u tekstu rada u vezi s bilj. 91-94.). To bi se gledište teže moglo braniti u pogledu koncepcije nevaljanosti ugovora de lege lata u ZOO-u jer, za razliku od odredbe čl. 368. st. 3. ZOO-a o uzajamnim vraćanjima nakon raskida ugovora, odredbe čl. 323. i 332. ZOO-a ne sadrže takvo izričito upućivanje, a i prema prevladavajućem stajalištu u hrvatskom pravu teorija preobrazbe neopravdano se ne prihvaća ni u pogledu raskida ugovora, već se drži da raskidom ugovora ugovorne obveze prestaju s učinkom ex tunc. Suprotno gledište, prema kojemu se raskidom ugovora ugovorni odnos preobražava u likvidacijski odnos prihvaća se u ovom radu u tekstu u vezi s bilj. 91-94, a u pravnoj književnosti argumentirao ga je: Miladin, P., Odnos, str. 1094. Za pregled prevladavajućih stajališta hrvatskoga prava o ex tunc učincima raskida ugovora vidi: Tot, I., Prestanak, str. 1173. Za pregled stajališta švicarskog i njemačkog prava u kojima je teorija preobrazbe glede raskida ugovora prihvaćena, kao i austrijskog prava u kojemu u tom pogledu, kao i u hrvatskom pravu, prevladava teorija o otpadanju pravnog temelja, vidi: ibid., str. 1176. Međutim, mjesta argumentaciji za stajalište o likvidacijskom odnosu među stranama nevaljanog ugovora, a posebno stranama pobojnog ugovora, ima i u okvirima ZOO-a de lege lata, no to se ostavlja za daljnja istraživanja.

126 Slično, vidi: VTSRH, XLVI Pž-2276/08-3 od 15. travnja 2008., dostupna na: Ius-Info, 19. siječnja 2019.

127 Usp.: Tot, I., Pojam, str. 60; Tot, I., Prestanak, str. 1179.

128 Usp.: Miladin, P., Markovinović, H., op. cit., str. 12.

129 Usp.: ibid., str. 25. Vidi i: Bukovac Puvača, M., Mihelčić, G., Pitanje naknade za učinjena ulaganja i vraćanje danog kod zakupa poslovnog prostora i najma stana, u: Slakoper, Z. (ur.), 
prema najmodavcu najmanje kondikcijski zahtjev za vraćanjem plaćenih najamnina. $\mathrm{K}$ tome, i brojni drugi različiti restitucijski i kondikcijski zahtjevi mogu nastati za obje strane zbog ispunjavanja različitih sporednih obveza tijekom trajanja najamnog odnosa kao trajnog obveznog odnosa. Upravo se zbog pravnih situacija kao što je ova iz navedenog primjera u poredbenom pravu ističe postojanje poteškoća u povratnom odvijanju trajnih obveznih odnosa, koje prema poredbenopravnim stajalištima opravdavaju ograničenje učinka nevaljanosti trajnih ugovora na učinak ex nunc.

\subsection{Ograničenje učinka nevaljanosti trajnog ugovora u hrvatskom pravu}

Rasprava o potrebi ograničenja učinka nevaljanosti trajnog ugovora na ex nunc učinak nije se za sada povela u hrvatskoj pravnoj književnosti, a u sudskoj se praksi nije znatnije problematičnim pokazalo povratno odvijanje trajnih obveznih odnosa zasnovanih nevaljanim trajnim ugovorima. Razlog tomu nije što u hrvatskom pravu, za razliku od poredbenoga, ne bi postojale poteškoće s povratnim odvijanjem trajnih obveznih odnosa, već u tome što se zahtjevi za novčanom restitucijom iz čl. 323. st. 1. i čl. 332. st. 1. ZOO-a i kondikcijski zahtjevi s osnova instituta neopravdanog obogaćenja u slučajevima ništetnosti i poništaja trajnih ugovora iz razloga pobojnosti u praksi gotovo i ne postavljaju. ${ }^{130}$ Notorno je da sud odlučuje u granicama zahtjeva stavljenih u postupku te da o zahtjevima za naturalnom i novčanom restitucijom i o zahtjevima za naknadom vrijednosti postignute koristi u postupcima koji se vode radi utvrđenja ništetnosti ugovora ili radi poništenja pobojnog ugovora ne može odlučivati ako oni nisu tužbom postavljeni. Uz činjenicu da ZOO, kao i poredbenopravni uzori, uređuje sve obvezne odnose promatrajući ih kroz prizmu odnosa koji su upravljeni

Liber amicorum in honorem Vilim Gorenc, Rijeka, Pravni fakultet Sveučilišta u Rijeci, 2014., str. 154-156.

130 Tako barem proizlazi iz analize objavljene i dostupne sudske prakse u vezi s primjenom odredaba čl. 323. st. 1. i čl. 332. st. 1. ZOO-a u slučajevima koji su se odnosili na nevaljanost trajnih ugovora, a koja je provedena u istraživanju u ovom radu. Tako je, primjerice, u jednom predmetu zbog prijevare zakupnika poništen ugovor o zakupu poslovnog prostora te je zakupniku naloženo vratiti poslovni prostor u posjed zakupodavca, no u tom predmetu zakupodavac kao tužitelj, osim zahtjeva za naturalnom restitucijom usmjerenog na vraćanje poslovnog prostora u neposredni posjed, nije istaknuo nikakav drugi zahtjev za novčanom restitucijom niti zahtjev s osnove neopravdanog obogaćenja zakupnika, a ni zakupnik nije istaknuo protutužbeni kondikcijski zahtjev za vraćanjem zakupnina plaćenih na temelju poništenog ugovora o zakupu: VSRH, Rev 1794/01-2 od 19. siječnja 2005. U jednom je predmetu usvojen tužbeni zahtjev za utvrđenjem ništetnosti ugovora o dosmrtnom uzdržavanju, no tužitelj nije u postupku istaknuo nikakav zahtjev za restitucijom: VSRH, Rev 24/07-2 od 4. travnja 2007. Slično tomu, u jednom je predmetu usvojen tužbeni zahtjev za utvrđenjem ništetnosti ugovora o zakupu hotela, no u postupku nisu istaknuti nikakvi drugi tužbeni ni protutužbeni zahtjevi: VSRH, Revt 68/07-2 od 24. listopada 2007. U jednom je predmetu utvrđeno da je ugovor o osiguranju imovine ništetan jer je u trenutku sklapanja ugovora osigurani slučaj već bio u nastupanju pa je sud odbio tužbeni zahtjev ugovaratelja osiguranja za isplatom osigurnine. U drugome je utvrđeno da je ugovor o osiguranju života ništetan jer je u trenutku sklapanja ugovora već nastao osigurani slučaj pa je odbio tužbeni zahtjev ugovaratelja osiguranja za isplatom osigurnine, no drugi moguće osnovani tužbeni i protutžbeni zahtjevi u tim predmetima nisu bili istaknuti: VSRH, Rev 26/092 od 21. srpnja 2010. i Rev-x 133/11-2 od 8. svibnja 2012. 
na jednokratnu razmjenu činidbi, a često i kroz prizmu samo ugovora o kupoprodaji, zbog čega posebnosti trajnih ugovora i trajnih obveznih odnosa naprosto promiču, vjerojatni uzrok neisticanju osnovanih zahtjeva u pravnoj praksi su i normativni deficiti zakonskog uređenja stjecanja bez osnove zbog kojih adresatima ZOO-a nije ni poznata široka lepeza kondikcijskih zahtjeva koji im stoje na raspolaganju. ${ }^{131} \mathrm{Od}$ pomoći adresatima ZOO-a u razjašnjenju obveznog odnosa među stranama ništetnog ili poništenog trajnog ugovora ponekad nije ni sudska praksa u kojoj se ponegdje pronalaze i teško shvatljive odluke. ${ }^{132}$

Kako bi se dao odgovor na pitanje je li u hrvatskom pravu moguće i opravdano prihvatiti poredbenopravno učenje o ograničenju učinka nevaljanosti trajnog ugovora na učinak ex nunc kao opće pravilo primjenjivo za sve trajne ugovore, najprije je potrebno raspraviti to pitanje na razini pojedinih tipova trajnih ugovora za koje se i u poredbenom pravu prihvaća ograničenje učinka nevaljanosti ugovora na djelovanje ex nunc.

Radni je odnos trajni obvezni odnos, ${ }^{133}$ a ugovor o radu je trajni ugovor. Zakon o radu ${ }^{134}$ ne sadrži odredbu koja bi sadržajno odgovarala odredbi čl. 320. st. 3. OR-a, prema kojoj je učinak nevaljanosti ugovora o radu u švicarskom pravu ograničen na učinak ex nunc. Put prihvaćanju učenja o ograničenju učinka nevaljanosti ugovora o radu ne otvara ni odredba čl. 14. st. 2. ZR-a, prema kojoj propust ugovornih strana da sklope ugovor o radu u pisanom obliku ,ne utječe na postojanje i valjanost toga ugovora“. U toj odredbi nije riječ o pravnoj fikciji da ugovor o radu postoji, već je riječ o tome da je ugovor o radu valjan i ako nije sklopljen u propisanom obliku iz čl. 14. st. 1. ZR-a. ${ }^{135}$ Također, stajalište je sudske prakse da se, tzv. faktični rad, kao što je to rad kod poslodavca, a da je ugovor o radu sklopljen makar konkludentno ili rad kod poslodavca nakon prestanka prethodnoga radnog odnosa bez sklopljenog novog ugovora o radu, ne može samo po obavljanju poslova za poslodavca smatrati radnim odnosom, posebno ako ne postoje i drugi elementi radnog odnosa. ${ }^{136} \mathrm{U}$ pravnoj se

$131 \mathrm{O}$ brojnim mogućim načinima neopravdanog obogaćenja te činidbenim i nečinidbenim kondikcijama koje stoje na raspolaganju kondikcijskom vjerovniku i u hrvatskom pravu de lege lata vidi: Miladin, P., Markovinović, H., op. cit., str. 5-30.

132 Tako je u jednom predmetu u kojemu je utvrđena ništetnost ugovora o kreditu, s pozivanjem na odredbe čl. 104. st. 1. ZOO/91 o obvezi naturalne restitucije, bilo naloženo banci kao tuženiku i protužitelju da korisniku kredita kao tužitelju i protutuženiku vrati iznose koje je primila na ime otplate glavnice kredita, a pritom je zbog proteka općeg zastarnog roka bio i odbijen protutužbeni zahtjev banke za vraćanjem iznosa glavnice kredita stavljenog na raspolaganje korisniku kredita. Vidi više u: VTSRH, 66. Pž-7359/13-3 od 16. prosinca 2015.

133 Tako i: VSRH, Revr 106/08-2 od 2. travnja 2008. i Revr 533/05-2 od 9. veljače 2006.; ŽS Varaždin, Gž.274/07-2 od 17. travnja 2007.

134 Zakon o radu, NN, br. 93/14. i 127/17. (dalje: ZR).

135 Prema stajalištima sudske prakse, ta se odredba odnosi na slučaj kada ugovor o radu postoji, samo nije sklopljen u propisanom pisanom obliku, a ne i na slučaj kada ugovor o radu ne postoji: VSRH, Revr 1105/14-2 od 30. lipnja 2015., Revr 100/13-2 od 9. rujna 2014., Revr 660/08-2 od 22. travnja 2009., Revr 659/08-2 od 14. siječnja 2009., Revr 638/08-2 od 14. siječnja 2009., Revr 225/08-2 od 13. kolovoza 2008., Rev 354/08-2 od 23. srpnja 2008. i Revr 770/06-2 od 10. siječnja 2007.; ŽS Split, Gž R-619/2018-2 od 8. studenoga 2018.

136 VSRH, Revr 1328/14-2 od 26. svibnja 2015., Revr 193/14-2 od 5. studenoga 2014., Revr 642/08-2 od 25. ožujka 2009., Revr-251/02-2 od 23. siječnja 2003., Revr-126/02-2 od 24. 
književnosti drži da je element koji određuje bit radnog odnosa ovisni rad radnika, tj. rad po uputama i pod nadzorom poslodavca, odnosno podređenost radnika poslodavcu zbog koje radnik kao slabija strana i uživa radnopravnu zaštitu. ${ }^{137}$ Prema odlukama iz sudske prakse u vezi, s tzv. faktičnim radom, i tzv. faktični radnik ima pravo na naknadu za obavljeni posao, ali ne temeljem ugovora o radu jer ugovor o radu nije sklopljen i radni odnos nije zasnovan. Međutim, ovdje se ne radi o primjeni učenja o faktičnim ugovornim odnosima, koje je prihvaćeno u švicarskom pravu te na kojemu je i utemeljena odredba čl. 320. st. 3. OR-a, a prema kojemu se fingira da je ugovor valjan, iako on nije valjan ili nije ni sklopljen. U slučajevima, tzv. faktičnog rada prije je riječ o tome da je između, tzv. faktičnog rada i poslodavca sklopljen ugovor o djelu ili ugovor o službi. Prema tome, za primjenu učenja o ograničenju učinka nevaljanosti trajnog ugovora na nevaljanost ugovora o radu u hrvatskom pravu ne postoji uporište ni u odredbama ZR-a ni u učenju o faktičnim ugovornim odnosima koje se ni inače ne primjenjuje u hrvatskom pravu. Međutim, opravdani razlozi za ograničenje učinka nevaljanosti ugovora o radu u hrvatskom pravu na učinak ex nunc postoje i oni su istovjetni kao i u poredbenom pravu. Tiču se specifičnog odnosa podređenosti radnika poslodavcu i posebne potrebe socijalne zaštite zbog koje ne bi bilo opravdano dopustiti povratno odvijanje radnog odnosa koji se već nalazi u stadiju odvijanja u vrijeme utvrđenja ništetnosti ili poništenja ugovora o radu zbog razloga pobojnosti. De lege lata bi se do ograničenja učinka nevaljanosti ugovora o radu na učinak ex nunc moglo doći teleološkom redukcijom odredaba čl. 323. st. 1. i čl. 332. st. 1. ZOO-a i tumačenjem odredbe čl. 116. st. 1. ZR-a na način da se razlozi ništetnosti i pobojnosti uzimaju kao „druge osobito važne činjenice“ zbog kojih nastavak radnog odnosa nije moguć, tj. da se oni uzimaju kao opravdani razlozi za izvanredni otkaz ugovora o radu.

Razlozi za ograničenje učinka nevaljanosti ugovora kojime se osniva društvo u hrvatskom pravu istovjetni su razlozima zbog kojih se učinak nevaljanosti takvih ugovora ograničuje na djelovanje ex nunc u poredbenom pravu. Tiču se ponajprije činjenice da neovisno o nevaljanosti ugovora o osnivanju društva ono faktično postoji i sudjeluje u pravnom prometu pa se javlja i potreba zaštite vjerovnika društva i ostalih trećih osoba koji sudjeluju u prometu s povjerenjem u postojanje društva. Donekle istovjetni rezultat, kao i ograničenjem učinka nevaljanosti ugovora o osnivanju društva, postiže se primjenom učenja o društvu s nedostatkom, koje je razvijeno u njemačkom pravu, a prihvaćeno je i u švicarskom te austrijskom pravu. Ono je prihvaćeno i u hrvatskom pravu društava te je odgovarajuće rješenje po uzoru na to učenje sadržano u propisima kojima se uređuju pojedina društva pravne osobe, u odredbama prema kojima je pravomoćna odluka suda o tome da je upis društva u odgovarajući registar bio nezakonit istaknuta kao jedan od razloga za prestanak društva. ${ }^{138}$ Društva pravne

svibnja 2002., Rev-1806/01-2 od 22. svibnja 2002. i Rev 1951/1997-2 od 3. prosinca 1997. Vidi i: ŽS Varaždin, Gž.413/10-2 od 3. svibnja 2010. i Gž. 378/09-2 od 7. travnja 2009., dostupne na: Ius-Info, 19. siječnja 2019.

137 Senčur Peček, D., Laleta, S., Ugovor o radu i ugovor o djelu: područje primjene radnog zakonodavstva, Zbornik Pravnog fakulteta Sveučilišta u Rijeci, vol. 39, 1/2018, str. 418.

138 Usp.: za javno trgovačko društvo, čl. 97. st. 3. Zakona o trgovačkim društvima (NN, br. 111/93., 34/99., 121/99., 52/00., 118/03., 107/07., 146/08., 137/09., 125/11., 152/11., 111/12., 68/13. i 
osobe prestaju tek brisanjem iz odgovarajućeg registra pa nevaljanost ugovora o osnivanju društva upisanog u odgovarajući registar nema ex tunc učinak u pogledu temeljnog namjeravanog učinka takvog ugovora, a taj je nastanak društva pravne osobe. ${ }^{139}$ Također, i mimo odredaba koje su u hrvatskom pravu odraz učenja o društvu s nedostatkom opravdano je i moguće teleološkom redukcijom odredaba čl. 323. st. 1. i čl. 332. st. 1. ZOO-a ograničiti učinak nevaljanosti ugovora o osnivanju društva na ex nunc učinak, posebno s obzirom na to da su oni po svojoj pravnoj prirodi posebni organizacijski ugovori na koje se i ne mogu primijeniti sva pravila koja vrijede za obveznopravne ugovore.

Društvo, no ne i društvo pravna osoba, nastaje i ugovorom o ortaštvu i ugovorom o tajnom društvu. Oni su trajni ugovori obveznog prava kojima se zasnivaju trajni obvezni odnosi, ${ }^{140}$ no oni su po svojoj pravnoj prirodi ujedno i organizacijski ugovori. ${ }^{141}$ Zbog te njihove dvojake pravne prirode, jednako kao i za ugovore o osnivanju društva pravne osobe, opravdano je teleološkom redukcijom odredaba čl. 323. st. 1. i čl. 332. st. 1. ZOO-a ograničiti učinak nevaljanosti ugovora o ortaštvu i ugovora o tajnom društvu na djelovanje ex nunc. Ovdje se, slično kao i kod ugovora o radu, može uzeti da se razlozi nevaljanosti ugovora pretvaraju u važne razloge za izvanredni otkaz ugovora o ortaštvu iz čl. 652. st. 3. ZOO-a, odnosno ugovora o tajnom društvu iz čl. 155. st. 2. ZTD-a, što je rješenje koje je za te ugovore i ranije bilo predloženo u pravnoj književnosti. ${ }^{142}$

Ograničenje učinka nevaljanosti trajnih ugovora na učinak ex nunc nije potpuna nepoznanica hrvatskom pravu. Prema odredbi čl. 932. st. 1. ZOO-a, osiguratelj ima pravo zahtijevati poništaj ugovor o osiguranju zbog prijevare pri sklapanju ugovora o osiguranju, a poništenje ugovora o osiguranju iz toga razloga pobojnosti ima učinak ex nunc. Prema odredbi čl. 932. st. 2. ZOO-a, u slučaju poništenja ugovora o osiguranju zbog prijevare pri sklapanju ugovora o osiguranju, osiguratelj ima pravo zadržati i naplatiti premije za razdoblje do dana podnošenja zahtjeva za poništenje ugovora, ali je obvezan plaćati osigurninu ako do toga dana nastupi osigurani slučaj. Istovjetan ex nunc učinak ima i poništenje ugovora o osiguranju zbog prijevarnog nadosiguranja, prema odredbama čl. 956. st. 1. i 2. ZOO-a. ${ }^{143}$ Iz tih se odredaba ZOO-a, međutim, ne bi moglo izvesti opće pravilo prema kojemu bi učinak poništenja trajnog

110/15.; dalje: ZTD); za komanditno društvo, čl. 132. u vezi s čl. 97. st. 3. ZTD-a; za dioničko društvo, čl. 367. st. 1. t. 3. ZTD-a; za društvo s ograničenom odgovornošću, uključujući i jednostavno društvo s ograničenom odgovornošću, čl. 466. st. 1. t. 5. ZTD-a; za gospodarsko interesno udruženje, čl. 585. st. 2. u vezi s čl. 97. st. 3. ZTD-a; za zadrugu, čl. 43. st. 1. t. 2. Zakona o zadrugama (NN, br. 34/11., 125/13., 76/14. i 114/18.); za udrugu sa svojstvom pravne osobe, čl. 48. st. 1. t. 4. Zakona o udrugama (NN, br. 74/14. i 70/17.); za ustanovu, čl. 71. t. 1. Zakona o ustanovama (NN, br. 76/93., 29/97., 47/99. i 35/08.).

139 Vidi o tome i o učenju o društvu s nedostatkom u: Barbić, J., Pravo društava - Knjiga prva Opći dio, Zagreb, Organizator, 2008., str. 142-146.

140 Tot, I., Pojam, str. 60; Tot, I., Prestanak, str. 1190.

141 Barbić, J., Društveni ugovor kao posao na kojem se temelji društvo, Zbornik Pravnog fakulteta u Zagrebu, vol. 62, 1-2/2012, str. 478-479 i 490-491.

142 Barbić, J., Pravo, str. 146.

143 O odredbama čl. 932. i čl. 956. ZOO-a vidi: Belanić, L., u: Gorenc, V., op. cit., str. 1506-1508 i 1558-1559. Vidi i: ŽS Rijeka, Gž-2212/2017 od 4. travnja 2018. 
ugovora zbog prijevare bio ograničen na djelovanje ex nunc pa takvo pravilo općom analogijom primijeniti i na sve druge trajne obvezne odnose. Ratio ograničenja učinka poništaja ugovora o osiguranju zbog prijevare je u tome što osiguratelj u ugovorima o osiguranju ima trajnu obvezu pripravnosti na činidbu isplate osigurnine koja ima oblik trpljenja. ${ }^{144}$ Ta se trajna obveza ne bi mogla jednostavno izraziti objektivnim novčanim ekvivalentom, pa bi u slučaju ex tunc učinka poništenja ugovora na njegov vlastiti zahtjev, zbog poteškoća s postavljanjem zahtjeva za novčanom restitucijom, osiguratelj neopravdano bio zakinut za naknadu za tu izvršavanu trajnu činidbu. Nasuprot tomu, kod poništenja ugovora zbog prijevare u ostalim tipovima trajnih ugovora, ex nunc učinak poništenja ugovora imao bi za posljedicu honoriranje prijevarnog postupanja jedne od strana.

Opće se pravilo o ograničenju učinka nevaljanosti svih trajnih ugovora na djelovanje ex nunc ne bi moglo prihvatiti za hrvatsko pravo de lege lata. Stajalište o takvom općem pravilu nema uporišta u odredbama ZOO-a jer, osim iznimke u vezi s ex nunc poništajem ugovora o osiguranju, ne postoje druge posebne odredbe kojima bi se ograničenje učinka nevaljanosti ugovora predviđalo za pojedine trajne obvezne odnose. Nije moguće iz znatnijeg brojega pojedinačnih pravila izvesti opće pravilo o ograničenju učinka nevaljanosti trajnih ugovora jer ni nema takvih pojedinačnih pravila kojima bi se ograničavao učinak nevaljanosti pojedinih trajnih ugovora. U hrvatskom obveznom pravu ne postoji niti jedna pravna norma usporediva s odredbom čl. 320 . st. 3. OR-a, da bi se takva pravna norma mogla uopćiti i primijeniti analogijom na sve trajne ugovore. Učenje o faktičnim ugovornim odnosima nije ranije primjenjivano u hrvatskom pravu. Ono je opterećeno manjkavostima zbog kojih je u njemačkom pravu u potpunosti napušteno, dok je u švicarskom pravu izloženo brojnim kritikama. Stoga ga ne bi bilo svrhovito uvoditi u hrvatsko pravo samo kako bi se opravdalo ograničenje učinka nevaljanosti trajnih ugovora.

Postojanje brojnih poteškoća s povratnim odvijanjem trajnog obveznog odnosa zasnovanog ništetnim trajnim ugovorom i trajnim ugovorom koji je poništen iz razloga pobojnosti je načelno i za hrvatsko pravo prihvatljiv argument za ograničenje učinka nevaljanosti trajnih ugovora u kojima se započelo s ispunjavanjem trajne obveze, odnosno koji se već nalaze u stadiju odvijanja prije isticanja nevaljanosti. Do tih poteškoća može doći zbog moguće kumulacije različitih zahtjeva koji svi proistječu iz iste činjenične osnove, izvršenja dužne činidbe $u$ ispunjenju pravno nepostojeće obveze iz ništetnog ili poništenog trajnog ugovora, i to: vlasničkog zahtjeva, obveznopravnog zahtjeva za naturalnom restitucijom, obveznopravnog zahtjeva za novčanom restitucijom, kondikcijskog zahtjeva za vraćanjem koristi stečene bez osnove, kondikcijskog zahtjeva za vraćanjem vrijednosti koristi stečene bez osnove, različitih drugih kondikcijskih zahtjeva zbog neopravdanog obogaćenja, zahtjeva za naknadom štete, te zahtjeva za kamatama i drugih sporednih zahtjeva. Zbog specifičnosti trajnih obveznih odnosa koja se očituje u tome što su oni upravljeni na trajnije obvezivanje, a ne na razmjenu jednokratnih činidbi, povratno odvijanje trajnog obveznog odnosa je sve teže što taj odnos duže traje. U trajnim obveznim odnosima kontinuirano se izvršavaju i sporedne činidbe, a za svaku od 
njih bi moglo doći do isticanja navedenih različitih zahtjeva. Često će biti teško pa i nemoguće utvrditi vrijednost izvršenih činidbi koje imaju oblik činidbe rada, trpljenja i propuštanja. Poteškoće s povratnim odvijanjem trajnog obveznog odnosa mogu nastati ne samo u vezi s nevaljanošću trajnog ugovora u kojemu tipična trajna obveza za predmet ima trajnu činidbu, već i ako tipična trajna obveza za predmet ima uzastopno ponavljanje izvršavanja jednokratnih činidbi davanja, primjerice u ugovorima s trajnom isporukom. ${ }^{145}$ Međutim, u okvirima hrvatske pravne stvarnosti, u kojoj se, čini se, problem poteškoća s povratnim odvijanjem trajnog obveznog odnosa nije znatnije realizirao jer stranke u sudskim postupcima ni ne ističu veći dio zahtjeva koji im moguće osnovano pripadaju, hipotetska mogućnost značajnih poteškoća s povratnim odvijanjem trajnog obveznog odnosa ne može se uzeti kao opravdan argument za modifikaciju učinka općeg privatnopravnog instituta kakav je institut nevaljanosti ugovora, barem ne u smislu da se pozivanjem na taj argument uspostavi opće pravilo o ex nunc učinku nevaljanosti ugovora koje bi se primjenjivalo na sve tipove trajnih ugovora.

Ograničenje učinka nevaljanosti trajnih ugovora na djelovanje ex nunc u hrvatskom je pravu moguće i opravdano prihvatiti u pogledu nevaljanosti ugovora o radu i nevaljanosti ugovora o osnivanju društva. Razlog tomu je jer ovdje postoji specifičan odnos međuovisnosti ugovornih strana te naglašenija potreba socijalne zaštite i povjerenja u pravni promet. Takvi, a ni usporedivi razlozi ne postoje u pogledu svih tipova trajnih ugovora pa se ni pozivanjem na takve pravnopolitičke razloge ne bi moglo konstruirati opće pravilo o ex nunc učinku nevaljanosti svih trajnih ugovora. Takvi bi se razlozi mogli, međutim, istaknuti i kao argument za ograničenje učinka nevaljanosti pojedinih drugih tipova trajnih ugovora, kao što je to, primjerice, ugovor o najmu stana ili ugovor o doživotnom uzdržavanju.

To što za hrvatsko pravo nije prihvatljivo opće pravilo o ex nunc učinku nevaljanosti trajnog ugovora ne znači i da se sud u konkretnom predmetu ne bi mogao, ako bi to okolnosti konkretnog slučaja opravdavale, pozvati na neki od pravnopolitičkih argumenata ili na argument brojnih poteškoća s povratnim odvijanjem trajnog obveznog odnosa, pa teleološkom redukcijom odredaba čl. 323. st. 1. i čl. 332. st. 1. ZOO-a u konkretnom slučaju ograničiti učinak nevaljanosti trajnog ugovora na djelovanje ex nunc. Teleološkom redukcijom kao metodom tumačenja prava sud se može poslužiti uvijek kad bi doslovna primjena pravnoga pravila polučila nepravično rješenje konkretnog slučaja.

U primjeni teleološke redukcije moglo bi se uzeti da se određeni razlog nevaljanosti ugovora, a posebno ako je riječ o razlozima pobojnosti, pojavio kao važan razlog za izvanredni otkaz ugovora koji djeluje samo pro futuro. Naime, istovjetno kao i u švicarskom, austrijskom i njemačkom pravu, i u hrvatskom pravu de lege lata vrijedi pravilo da svaki trajni obvezni odnos, neovisno o tome je li zasnovan na neodređeno ili na određeno vrijeme, može na izvanredan način prestati

145 Za pojam ugovora s trajnom isporukom i razgraničenje tog ugovora od ugovora s uzastopnim ili sukcesivnim isporukama te od ugovora s ispunjenjem obveze isporuke u dijelovima vidi: ibid., str. 60-63. 
izvanrednim otkazom iz važnog razloga ${ }^{146}$ Ovisno o okolnostima konkretnog slučaja, povratno odvijanje trajnog obveznog odnosa moglo bi se odbiti i s obrazloženjem da je, s obzirom na izvjesno duže vrijeme u kojemu su strane nevaljanog trajnog ugovora ispunjavale obveze, pozivanje na ex tunc učinak nevaljanosti protivno načelu savjesnosti i poštenja te načelu zabrane zlouporabe prava. Kao i u poredbenom pravu, valjalo bi svakako prihvatiti stajalište da, unatoč svim drugim mogućim argumentima u prilog ograničenju učinka nevaljanosti trajnog ugovora, nikako nije prihvatljivo ograničiti učinak nevaljanosti trajnog ugovora na djelovanje ex nunc, ako je razlog nevaljanosti osobito bitna povreda pravnog poretka, kao što je to, samo primjerice, protivnost sadržaja ugovora moralu društva.

\section{ZAKLJUČAK}

Istraživanje je stajališta hrvatskom pravu usporednih pravnih poredaka švicarskog, austrijskog i njemačkog prava o ograničenju učinka nevaljanosti trajnih ugovora na djelovanje ex nunc pokazalo da je učenje o ograničenju učinka nevaljanosti trajnih ugovora najplodnije tlo pronašlo u švicarskom pravu. U austrijskom se pravu od prvotnoga prihvaćanja tog učenja kao općeg pravila ono dalje razvija u smjeru sužavanja njegove primjene na sve ograničeniji broj slučajeva. U njemačkom pravu to učenje nije prihvaćeno kao opće za sve tipove trajnih ugovora, ali se iz pravnopolitičkih razloga primjenjuje na pojedine tipove trajnih ugovora. Razlike u opsegu prihvaćanja tog učenja između švicarskog i austrijskog prava s jedne strane te njemačkog prava s druge vjerojatno su posljedica različitoga koncepta stjecanja prava vlasništva temeljem pravnog posla. U švicarskom i austrijskom pravu zbog prihvaćanja načela kauzalne tradicije, iz istoga činjeničnog stanja, izvršenja dužne činidbe u ispunjenju pravno nepostojeće obveze preuzete nevaljanim trajnim ugovorom, može proizaći više različitih zahtjeva pa zbog toga dolazi i do znatnih poteškoća s povratnim odvijanjem trajnog obveznog odnosa. U njemačkom je pravu zbog prihvaćanja načela apstraktne tradicije povratno odvijanje trajnog obveznog odnosa bez većih poteškoća moguće provesti primjenom isključivo pravila o neopravdanom obogaćenju. Učenje o ograničenju učinka nevaljanosti trajnih ugovora najšire je prihvaćeno u švicarskom pravu jer uporište za primjenu tog učenja postoji u zakonskom tekstu, u odredbi čl. 320. st. 3. OR-a, koju se bez većih dogmatskih poteškoća moglo uopćiti i analogijom primijeniti na sve trajne obvezne odnose, a osim toga je $\mathrm{i}$ učenje o faktičnim ugovornim odnosima objeručke prihvatio BGE. U austrijskom pravu, u kojem nema čvrstog uporišta za učenje o ograničenju učinka nevaljanosti trajnih ugovora u odredbama ABGB-a, prvotno olako u sudskoj praksi OGH-a prihvaćen je stav o prihvatljivosti tog učenja na razini općeg pravnog pravila primjenjivog za sve tipove pobojnih trajnih ugovora i sve razloge pobojnosti, postupno je sužavan i u pogledu tipova trajnih ugovora na koje se to pravilo može primijeniti i u pogledu razloga pobojnosti u

146 Za hrvatsko pravo de lege lata to proizlazi izvođenjem općeg pravila iz posebnih zakonskih odredaba kojima je za pojedine trajne obvezne odnose predviđeno pravo na otkaz iz važnih razloga općenito te onih kojima su konkretizirani važni razlozi za otkaz pojedinih trajnih obveznih odnosa. Vidi o tome: Tot, I., Prestanak, str. 1187-1196. 
odnosu na koje je to učenje prihvatljivo. Važna okolnost, koja je vjerojatno utjecala na razvijanje tog učenja u suprotnim smjerovima u švicarskom i austrijskom pravu, jest i što se u austrijskom pravu pobojni pravni posao, prema još uvijek prevladavajućem stajalištu austrijskog prava, u pravilu pobija konstitutivnom tužbom i poništava konstitutivnom presudom, dok se u švicarskom pravu, kao i u njemačkom pravu, on pobija jednostranim preobražajnim očitovanjem volje. Stajalište austrijskog prava o primjenjivosti učenja o ograničenju učinka nevaljanosti trajnih ugovora u slučaju ništetnosti trajnog ugovora nije sasvim izvjesno, no čini se da se austrijsko pravo opire protezanju tog učenja na ništetnost trajnog ugovora. O tome se može zaključiti iz okolnosti da to učenje nije više prihvaćeno ni u pogledu težih razloga pobojnosti trajnog ugovora, kao što su to prijevara i prijetnja, a poništaj trajnog ugovora s učinkom ex nunc ne može se zahtijevati ni u svim slučajevima pobojnosti ugovora zbog bitne zablude.

Istraživanje stajališta hrvatskoga prava o pravnim posljedicama nevaljanosti trajnih ugovora zasebno i u vezi s rezultatima poredbenopravne metode dovodi do zaključka da za hrvatsko pravo nije prihvatljivo stajalište prema kojemu bi glede nevaljanosti trajnih ugovora kao opće pravilo vrijedilo ono o ograničenju učinka nevaljanosti trajnih ugovora na djelovanje ex nunc. Međutim, učenje o ograničenju učinka nevaljanosti trajnog ugovora opravdano je, iz pravnopolitičkih razloga, i moguće prihvatiti kao pravilo za ex nunc učinak nevaljanosti pojedinih tipova trajnih ugovora, kao što je to ugovor o radu i ugovor o osnivanju društva, ali i kao iznimku od općeg učinka nevaljanosti ugovora u konkretnim slučajevima u kojima bi primjena te iznimke dovela do pravičnijeg rješenja. I za jedno i za drugo je de lege lata moguće poslužiti se teleološkom redukcijom odredaba čl. 323. st. 1. i čl. 332. st. 1. ZOO-a.

\section{LITERATURA}

\section{A. Knjige}

1. Bamberger, Heing Georg, Roth, Herbert, Hau, Wolfgang, Poseck, Roman (ur.), Beck'scher Online-Kommentar Bürgerliches Gesetzbuch, München, C. H. Beck, 2017.

2. Barbić, Jakša, Pravo društava - Knjiga prva - Opći dio, Zagreb, Organizator, 2008.

3. Barta, Heinz (ur.), Zivilrecht - Grundriss und Einführung in das Rechtsdanken, Wien, Facultas Verlags- und Buchhandels, 2004.

4. Binder, Andreas, Geiser, Thomas, Roberto, Vito, Einführung ins Privatrecht, St. Gallen, Universität St. Gallen, 2008.

5. Blank, Hubert, Börstinghaus, Ulf P., Miete - Das gesamte BGB-Mietrecht - Kommentar, München, C. H. Beck, 2008.

6. Boemke, Burkhard, Ulrici, Bernhard, BGB Allgemeiner Teil, Berlin - Heidelberg, Springer, 2014.

7. Bucher, Eugen, Schweizerisches Obligationenrecht - Allgemeiner Teil ohne Deliktsrecht, Zürich, Schulthess Polygraphischer Verlag, 1988.

8. Bydlinski, Peter, Bürgerliches Recht - Band I - Allgemeiner Teil, Wien - New York, Springer, 2007.

9. Crnić, Ivica, Zakon o obveznim odnosima - Opsežna sudska praksa, napomene i komentari, detaljno abecedno kazalo pojmova, Zagreb, Organizator, 2016.

10. Flume, Werner, Allgemeiner Teil des Bürgerlichen Rechts - Zweiter Band - Das Rechtsgeschäft, Berlin - Heidelberg, Springer, 1992. 
11. Gauch, Peter, Schluep, Walter R., Schmid, Jörg, Rey, Heinz, Schweizerisches Obligationenrecht - Allgemeiner Teil - Band I, Zürich, Schulthess Polygraphischer Verlag, 1998.

12. Gavella, Nikola (red.), Stvarno pravo, Zagreb, Informator, 1998.

13. Gorenc, Vilim (red.), Komentar Zakona o obveznim odnosima, Zagreb, Narodne novine, 2014.

14. Gschnitzer, Franz, Allgemeiner Teil des bürgerlichen Rechts, Wien, Springer Verlag, 1966.

15. Honsell, Heinrich, Vogt, Nedim P., Wiegand, Wolfgang (ur.), Basler Kommentar zum Schweizerischen Privatrecht - Obligationenrecht I - Art. 1-529 OR, Basel - Genf München, Helbing \& Lichtenhahn, 2003.

16. Hromadka, Wolfgang, Maschmann, Frank, Arbeitsrecht - Band 1 - Individualarbeitsrecht, Berlin - Heidelberg, Springer, 2015.

17. Kiel, Heinrich, Lunk, Stefan, Oetker, Hartmut (red.), Münchener Handbuch zum Arbeitsrecht - Individualarbeitsrecht I, München, C. H. Beck, 2018.

18. Klarić, Petar, Vedriš, Martin, Građansko pravo, Zagreb, Narodne novine, 2009.

19. Kletečka, Andreas, Schauer, Martin (ur.), ABGB-ON - Kommentar zum Allgemeinen bürgerlichen Gesetzbuch, Wien, Manzsche Verlags- und Universitätsbuchhandlung, 2010.

20. Konstantinović, Mihailo, Obligacije i ugovori - Skica za Zakonik o obligacijama i ugovorima, Beograd, Pravni fakultet u Beogradu, 1969.

21. Koziol, Helmut, Bydlinski, Peter, Bollenberger, Raimund (ur.), Kurzkommentar zum ABGB, Wien - New York, Springer, 2010.

22. Koziol, Helmut, Welser, Rudolf, Kletečka, Andreas, Grundriss des bürgerlichen Rechts Band I - Allgemeiner Teil, Sachenrecht, Familienrecht, Wien, MANZ'sche Verlags- unf Universitätsbuchhandlung, 2014.

23. Larenz, Karl, Canaris, Claus-Wilhelm, Methodenlehre der Rechtswissenschaft, Berlin Heidelberg, Springer, 1995.

24. Marhold, Franz, Friedrich, Michael, Österreichisches Arbeitsrecht, Wien - New York, Springer, 2012.

25. Markovinović, Hrvoje, Ugovor o cesiji, doktorska disertacija, Zagreb, Pravni fakultet Sveučilišta u Zagrebu, 2005.

26. Oetker, Hartmut i Maultzsch, Felix, Vertragliche Schuldverhältnisse, Berlin - Heidelberg - New York, Springer, 2013.

27. Palandt, Otto (red.), Palandt - Bürgerliches Gesetzbuch, München, C. H. Beck, 2003.

28. Rolfs, Christian, Giesen, Richard, Kreikebohm, Ralf, Udsching, Peter (red.), Beck'scher Online-Kommentar Arbeitsrecht, München, C. H. Beck, 2018.

29. Schaub, Günter (red.), Arbeitsrechts-Handbuch, München, C. H. Beck, 2017.

30. Schubert, Claudia (red.), Münchener Kommentar zum Bürgerlichen Gesetzbuch: BGB Band 1: Allgemeiner Teil $\S \S 1-240$, AllgPersönlR, ProstG, AGG, München, C. H. Beck, 2018.

31. Schulze, Reiner (red.), Bürgerliches Gesetzbuch - Handkommentar, Baden-Baden, Nomos, 2019.

32. Schwenzer, Ingebort, Schweizerisches Obligationenrecht - Allgemeiner Teil, Bern, Stämpfli Verlag, 2003.

33. Schwimann, Michael (ur.), ABGB Taschenkommentar, Wien, LexisNexis Verlag, 2013.

34. Slakoper, Zvonimir, Gorenc, Vilim, Bukovac Puvača, Maja, Obvezno pravo - Opći dio Sklapanje, promjene i prestanak ugovora, Zagreb, Novi informator, 2009.

35. Stürner, Rolf (red.), Jauernig - Bürgerliches Gezetzbuch: Kommentar, München, C. H. Beck, 2018.

36. Zerres, Thomas, Bürgerliches Recht, Berlin - Heidelberg, Springer, 2010. 


\section{B. Članci i poglavlja u knjizi}

1. Barbić, Jakša, Društveni ugovor kao posao na kojem se temelji društvo, Zbornik Pravnog fakulteta u Zagrebu, vol. 62, 1-2/2012, str. 475-534.

2. Bukovac Puvača, Maja, Mihelčić, Gabrijela, Pitanje naknade za učinjena ulaganja i vraćanje danog kod zakupa poslovnog prostora i najma stana, u: Slakoper, Zvonimir (ur.), Liber amicorum in honorem Vilim Gorenc, Rijeka, Pravni fakultet Sveučilišta u Rijeci, 2014., str. 131-156.

3. Held, Henrik-Riko, Neki problemi suvremenog uređenja stjecanja bez osnove, Hrvatska pravna revija, vol. 15, 12/2015, str. 13-18.

4. Honsell, Heinrich, 100 Jahre Schweizerisches Obligationenrecht, Zeitschrift für schweizerisches Recht, vol. 130, 2/2011, str. 5-115.

5. Kramer, Ernst. A., Der Einfluß des BGB auf das schweizerische und österreichische Privatrecht, Archiv für die civilistische Praxis, vol. 200, 3-4/2000, str. 365-400.

6. Miladin, Petar, Odnos kondikcijskog i drugih srodnih imovinskopravnih zahtjeva, u: Uzelac, Alen, Garašić, Jasna i Maganić, Aleksandra (ur.), Djelotovorna pravna zaštita u pravičnom postupku - Izazovi pravosudnih transformacija na jugu Europe - Liber amicorum Mihajlo Dika, Zagreb, Pravni fakultet Sveučilišta u Zagrebu, 2013., str. 10831105 .

7. Miladin, Petar, Problem vraćanja poduzeća stečenog na temelju ništavog ugovora o kupoprodaji poduzeća, Zbornik Pravnog fakulteta u Zagrebu, vol. 61, 2/2011, str. 743784.

8. Miladin, Petar, Markovinović, Hrvoje, Obogaćenje kao pretpostavka neopravdanog obogaćenja (stjecanja bez osnove), Zbornik Pravnog fakulteta u Zagrebu, vol. 68, 1/2018, str. 5-30.

9. Nikšić, Saša, Imovina u građanskom pravu, Zbornik Pravnog fakulteta u Zagrebu, vol. 62, 5-6/2012, str. 1599-1633.

10. Nikšić, Saša, Pravna sredstva za pobijanje nevaljanih pravnih poslova - ostvarivanje preobražajnog prava ili konstitutivna tužba?, Zbornik Pravnog fakulteta u Zagrebu, vol. 65, 3-4/2015, str. 361-386.

11. Radolović, Aldo, Nevaljanost pravnih poslova, u: Baretić, M., et al., Novi Zakon o obveznim odnosima - Najznačajnije izmjene - Novi instituti, Zagreb, Inženjerski biro, 2005., str. 88-130.

12. Richardi, Reinhard, Dienstvertrag, u: Martinek, Michael (red.), J. von Staudingers Kommentar zum Bürgerlichen Gesetzbuch mit Einführungsgesetz und Nebengesetzen Eckpfeiler des Zivilrechts, Berlin, Sellier - de Gruyter, 2010., str. 685-732.

13. Senčur Peček, Darja, Laleta, Sandra, Ugovor o radu i ugovor o djelu: područje primjene radnog zakonodavstva, Zbornik Pravnog fakulteta Sveučilišta u Rijeci, vol. 39, 1/2018, str. 411-456.

14. Slakoper, Zvonimir, Ugovor o zajmu, u: Slakoper, Zvonimir (red.), Bukovac Puvača, Maja, Mihelčić, Gabrijela (ur.), Bankovni i financijski ugovori, Zagreb, Narodne novine, 2017., str. 528-564.

15. Schiemann, Gottfried, Das Rechtsgeschäft, u: Martinek, Michael (red.), J. von Staudingers Kommentar zum Bürgerlichen Gesetzbuch mit Einführungsgesetz und Nebengesetzen Eckpfeiler des Zivilrechts, Berlin, Sellier - de Gruyter, 2010., str. 43-122.

16. Schwenzer, Ingebort, Rezeption deutschen Rechtsdenkens im schweizerischen Obligationenrecht, u: Schwenzer, I. (ur.), Schuldrecht, Rechtsvergleichung und Rechtsvereinheitlichung an der Schwelle zum 21. Jahrhundert: Symposium aus Anlass des 65. Geburtstages von Peter Schlechtriem, Tübingen, Mohr Siebeck, 1999., str. 59-88.

17. Tot, Ivan, Pojam trajnog obveznog odnosa, Pravni vjesnik, vol. 34, 2/2018, str. 57-72.

18. Tot, Ivan, Prestanak trajnih obveznih odnosa, Zbornik Pravnog fakulteta Sveučilišta u Rijeci, vol. 39, 3/2018, str. 1171-1206. 
19. Tumbri, Tanja, Restitucija kao posljedica ništavosti ugovora, Zbornik Pravnog fakulteta u Zagrebu, vol. 46, 5/1996, str. 455-471.

20. Weller, Marc-Philippe, Der Mietvertrag als enfant terrible der Privatrechtsdogmatik?, Juristen Zeitung, vol. 67, 18/2012, str. 881-891.

21. Wiegand, Wolfgang, Zur Rückabwicklung gescheiterter Verträge, u: Tercier, Pierre i dr. (ur.), Gauchs Welt - Festschrift für Peter Gauch zum 65. Geburtstag, Zürich, Schulthess, 2004., str. 709-722.

\section{Propisi}

1. Allgemeines bürgerliches Gesetzbuch für die gesammten deutschen Erbländer der Oesterreichischen Monarchie, JGS br. 946/1811., s posljednjom izmjenom od 22. prosinca 2018., BGB1 I br. 100/18.

2. Bundesgesetz vom 30. März 1911 betreffend die Ergänzung des Schweizerischen Zivilgesetzbuches (Fünfter Teil: Obligationenrecht), AS 27 317, s posljednjom izmjenom od 1. travnja 2017., AS 20172077

3. Bürgerliches Gesetzbuch in der Fassung der Bekanntmachung vom 2. Januar 2002, BGB1 I br. 2/02., s posljednjom izmjenom od 12. srpnja 2018., BGB1 I br. 26/18.

4. Zakon o obveznim odnosima, NN, br. 35/05., 41/08., 125/11., 78/15. i 29/18.

5. Zakon o obveznim odnosima, NN, br. 53/91., 73/91., 111/93., 3/94., 7/96., 91/96., 112/99. i $88 / 01$.

6. Zakon o obveznim odnosima, Sl. 1. SFRJ, br. 29/78., 39/85. i 57/89.

7. Zakon o radu, NN, br. 93/14. i 127/17.

8. Zakon o trgovačkim društvima, NN, br. 111/93., 34/99., 121/99., 52/00., 118/03., 107/07., 146/08., 137/09., 125/11., 152/11., 111/12., 68/13. i 110/15.

9. Zakona o udrugama, NN, br. 74/14. i 70/17.

10. Zakona o ustanovama, NN, br. 76/93., 29/97., 47/99. i 35/08.

11. Zakon o vlasništvu i drugim stvarnim pravima, NN, br. 91/96., 68/98., 137/99., 22/00., 73/00., 129/00., 114/01., 79/06., 141/06., 146/08., 38/09., 153/09., 143/12. i 152/14.

12. Zakon o zadrugama, NN, br. 34/11., 125/13., 76/14. i 114/18.

\section{Sudska praksa}

Hrvatska, Republika

1. Vrhovni sud Republike Hrvatske (VSRH), Visoki trgovački sud Republike Hrvatske (VTSRH), županijski sud (ŽS).

2. Sve odluke dostupne na: VSRH, Portal sudske prakse, <https://sudskapraksa.csp.vsrh. hr>, 19. siječnja 2019

3. VSRH, Rev 1951/1997-2 od 3. prosinca 1997.

4. VSRH, Rev 514/1996-2 od 17. veljače 2000.

5. VSRH, Rev-1806/01-2 od 22. svibnja 2002.

6. VSRH, Revr-126/02-2 od 24. svibnja 2002.

7. VSRH, Rev-2257/1997-2 od 18. lipnja 2002.

8. VSRH, Revr-251/02-2 od 23. siječnja 2003.

9. VSRH, Rev-746/00-2 od 9. srpnja 2003.

10. VSRH, Rev 3158/1999-2 od 16. srpnja 2003.

11. VSRH, Rev-188/02-2 od 22. srpnja 2003.

12. VSRH, Rev-1509/00-2 od 27. kolovoza 2003.

13. VSRH, Rev 531/00-2 od 10. rujna 2003..

14. VSRH, Rev 1239/01-2 od 19. studenoga 2003.

15. VSRH, Rev 2579/00-2 od 17. ožujka 2004.

16. VSRH, Rev 853/02-2 od 15. rujna 2004.

17. VSRH, Rev 1794/01-2 od 19. siječnja 2005.

18. VSRH, Rev 392/04-2 od 6. travnja 2005. 
19. VSRH, Rev 1347/01-2 od 5. listopada 2005.

20. VSRH, Rev 282/05-2 od 16. studenoga 2005.

21. VSRH, Rev 1794/01-2 od 19. siječnja 2005.

22. VSRH, Revr 533/05-2 od 9. veljače 2006.

23. VSRH, Rev 141/06-2 od 22. veljače 2006.

24. VSRH, Revr 770/06-2 od 10. siječnja 2007.

25. VSRH, Rev 24/07-2 od 4. travnja 2007.

26. VSRH, Rev 898/05-2 od 11. travnja 2007.

27. VSRH, Rev 299/07-2 od 18. travnja 2007.

28. VSRH, Revt 68/07-2 od 24. listopada 2007.

29. VSRH, Rev 729/06-2 od 29. studenoga 2007.

30. VSRH, Rev 1040/07-2 od 10. siječnja 2008.

31. VSRH, Revr 106/08-2 od 2. travnja 2008.

32. VSRH, Rev 354/08-2 od 23. srpnja 2008.

33. VSRH, Revr 225/08-2 od 13. kolovoza 2008.

34. VSRH, Revr 659/08-2 od 14. siječnja 2009.

35. VSRH, Revr 638/08-2 od 14. siječnja 2009.

36. VSRH, Revr 642/08-2 od 25. ožujka 2009.

37. VSRH, Revr 660/08-2 od 22. travnja 2009.

38. VSRH, Rev 26/09-2 od 21. srpnja 2010.

39. VSRH, Rev 589/10-2 od 26. listopada 2010.

40. VSRH, Rev 199/10-2 od 15. rujna 2011.

41. VSRH, Rev-x 133/11-2 od 8. svibnja 2012.

42. VSRH, Rev-x 808/11-2 od 12. rujna 2012.

43. VSRH, Rev-x 474/10-2 od 21. svibnja 2013.

44. VSRH, Rev-x 183/11-2 od 16. listopada 2013.

45. VSRH, Rev 369/10-2 od 18. ožujka 2014.

46. VSRH, Rev-x 529/13-2 od 25. ožujka 2014.

47. VSRH, Rev 933/09-2 od 23. travnja 2014.

48. VSRH, Revr 100/13-2 od 9. rujna 2014.

49. VSRH, Rev-x 633/10-2 od 1. listopada 2014.

50. VSRH, Rev 965/09-2 od 7. listopada 2014.

51. VSRH, Rev 2398/10-2 od 15. listopada 2014.

52. VSRH, Rev 247/11-3 od 22. listopada 2014.

53. VSRH, Revr 193/14-2 od 5. studenoga 2014.

54. VSRH, Rev 1809/11-2 od 10. veljače 2015.

55. VSRH, Rev 1666/11 od 6. svibnja 2015.

56. VSRH, Revr 1328/14-2 od 26. svibnja 2015.

57. VSRH, Rev 2781/11-2 od 16. lipnja 2015.

58. VSRH, Rev-x 511/12-2 od 28. travnja 2015.

59. VSRH, Revr 1105/14-2 od 30. lipnja 2015.

60. VSRH, Rev 1626/15-3 od 18. studenoga 2015.

61. VSRH, Rev-x 93/15-2 od 16. prosinca 2015.

62. VSRH, Rev-x 126/16-2 od 8. veljače 2017.

63. VTSRH, XLVI Pž-2276/08-3 od 15. travnja 2008., dostupna na: Portal Ius-Info, <http:// www.iusinfo.hr/>, 19. siječnja 2019.

64. VTSRH, 66. Pž-7359/13-3 od 16. prosinca 2015.

65. ŽS Rijeka, Gž-2212/2017 od 4. travnja 2018.

66. ŽS Split, Gž-1565/17-2 od 6. srpnja 2017.

67. ŽS Split, Gž-281/2017-2 od 1. veljače 2018.

68. ŽS Split, Gž-943/2018-2 od 19. travnja 2018.

69. ŽS Split, Gž R-619/2018-2 od 8. studenoga 2018. 
70. ŽS Varaždin, Gž.274/07-2 od 17. travnja 2007.

71. ŽS Varaždin, Gž.797/07-2 od 15. siječnja 2008.

72. ŽS Varaždin, Gž.851/08-2 od 2. lipnja 2008.

73. ŽS Varaždin, Gž.1428/08-2 od 8. prosinca 2008.

74. ŽS Varaždin, Gž. 378/09-2 od 7. travnja 2009., dostupna na: Portal Ius-Info, <http://www. iusinfo.hr/>, 19. siječnja 2019.

75. ŽS Varaždin, Gž.413/10-2 od 3. svibnja 2010.

76. ŽS Varaždin, 24 Gž-777/15-3 od 25. travnja 2017.

77. ŽS Zadar, 13 Gž-1150/18-2 od 9. studenoga 2018.

Njemačka, Savezna Republika

1. Bundesarbeitsgericht (BAG), Bundesgerichtshof (BGH), Oberlandesgericht (OLG), Landesgericht (LG). Sve odluke dostupne na: Jurion - Das Rechtsportal, <https://www. jurion.de/>, 19. siječnja 2019.

2. BAG, 1 AZR 189/57 od 15. studenoga 1957.

3. BAG, 2 AZR 145/67 od 18. travnja 1968.

4. BAG, 5 AZR 512/71 od 7. lipnja 1972.

5. BAG, 2 AZR 228/80 od 16. rujna 1982.

6. BAG, 7 AZR 34/83 od 29. kolovoza 1984.

7. BAG, 2 AZR 754/97 od 3. prosinca 1998.

8. BAG, 5 AZR 592/03 od 3. studenoga 2004.

9. BGH, II ZR 18/51 od 24. listopada 1951.

10. BGH, II ZR 167/53 od 12. svibnja 1954.

11. BGH, II ZR 82/70 od 14. prosinca 1972.

12. BGH, II ZR 127/74 od 11. ožujka 1976.

13. BGH, XII ZR 67/06 od 6. kolovoza 2008.,

14. BGH, XI ZR 252/08 od 10. studenoga 2009.

15. BGH, XII ZR 192/08 od 11. kolovoza 2010.

16. BGH, XII ZR 123/09 od 11. kolovoza 2010.

17. Kammergericht Berlin, 8 U 223/08 od 28. svibnja 2009., dostupno na: Judicialis Rechtsprechung, <https://www.judicialis.de/>, 19. siječnja 2019.

18. LG Hamburg, 316 S 104/10 od 20. rujna 2011., dostupno na: Judicialis Rechtsprechung, $<$ https://www.judicialis.de/>, 19. siječnja 2019.

19. LG Freiburg, 3 S 98/18 od 12. listopada 2018., dostupno na: Judicialis Rechtsprechung, $<$ https://www.judicialis.de/>, 19. siječnja 2019.

20. OLG Brandenburg, 3 U 5/03 od 11. studenoga 2009., dostupno na: OpenJur - die freie juristische Datenbank, <https://openjur.de/>, 19. siječnja 2019.

21. OLG Hamburg, 4 U 8/12 od 17. kolovoza 2012., dostupno na: OpenJur - die freie juristische Datenbank, <https://openjur.de/>, 19. siječnja 2019.

Republika Austrija

1. Oberster Gerichtshof (OGH). Sve odluke dostupne na: Bundeskanzleramt Rechtsinformationssystem - Justiz, <https://www.ris.bka.gv.at/>, 19. siječnja 2019.

2. OGH, 4 Ob 138/62 od 27. studenoga 1962.

3. OGH, 4 Ob 57/68 od 5. studenoga 1968.

4. OGH, $1 \mathrm{Ob} 62 / 71$ od 13. svibnja 1971.

5. OGH, 8 Ob 276/71 od 16. studenoga 1971.

6. OGH, 7 Ob 533/82 od 15. lipnja 1982.

7. OGH, 7 Ob 689/82 od 27. siječnja 1983.

8. OGH, $4 \mathrm{Ob} 76 / 82$ od 26. travnja 1983.

9. OGH, $4 \mathrm{Ob} 67 / 83$ od 25 . rujna 1984 ..

10. OGH, $4 \mathrm{Ob}$ 141/84 od 28. siječnja 1986. 
11. OGH, $1 \mathrm{Ob} 650 / 88$ od 11. listopada 1988.

12. OGH, 1 Ob 27/89 od 15. studenoga 1989.

13. OGH, 6 Ob 691/89 od 18. siječnja 1990.

14. OGH, 3 Ob 516/90 od 13. lipnja 1990.

15. OGH, $1 \mathrm{Ob} 685 / 90$ od 18. rujna 1991.

16. OGH, 8 Ob 644/91 od 10. rujna 1992.

17. OGH, 8 Ob 12/93 od 16. rujna 1993.

18. OGH, 7 Ob 515/95 od 27. siječnja 1995.

19. OGH, 2 Ob 511/95 od 23. veljače 1995.

20. OGH, 5 Ob 508/95 od 14. ožujka 1995.

21. OGH, 8 Ob 39/95 od 8. veljače 1996.

22. OGH, 5 Ob 2267/96k od 8. listopada 1996.

23. OGH, 1 Ob 2169/96v od 26. studenoga 1996.

24. OGH, 2 Ob 131/97x od 26. lipnja 1997.

25. OGH, 8 Ob S315/97z od 13. siječnja 1998.

26. OGH, 6 Ob 81/99a od 28. svibnja 1999.

27. OGH, $4 \mathrm{Ob} 233 / 00 \mathrm{v}$ od 24. listopada 2000.

28. OGH, $6 \mathrm{Ob} 257 / 08 \mathrm{z}$ od 17. prosinca 2008.

29. OGH, 6 Ob 69/08b od 2. srpnja 2009.

30. OGH, 7 Ob 77/10i od 30. ožujka 2011 .

31. OGH, 5 Ob 193/17v od 20. studenoga 2017.

32. OGH, $1 \mathrm{Ob}$ 122/18z od 26. rujna 2018.

Švicarska Konfederacija

1. Bundesgericht (BGE). Sve odluke dostupne na: Bundesgericht Rechtsprechung, $<$ https:// www.bger.ch/index.htm>, 19. siječnja 2019.

2. BGE, 110 II 244 od 5. rujna 1984.

3. BGE, 129 III 320 od 21. veljače 2003.

4. BGE, 132 III 242 od 23. studenoga 2005.

5. BGE, 134 III 438 od 12. lipnja 2008.

6. BGE, 137 III 243 od 3. svibnja 2011. 


\title{
Ivan Tot*
}

\author{
Summary
}

\section{LEGAL CONSEQUENCES OF THE INVALIDITY OF CONTINUING CONTRACTS}

The invalidity of contract in Croatian law, as well as in Swiss, Austrian, and German law, in principle has ex tunc effect. One of the legal consequences of the invalidity of contract is the obligation of restitution that arises when one of the parties provides the other with an act of performance in fulfilment of an obligation under an invalid contract, while the rules on unjustified enrichment are also to be applied to the obligation relationship between the parties. According to a legal standpoint found in Swiss, Austrian, and German law, in relation to continuing contracts, in cases where the provision of a continuing obligation has already begun, the effect of invalidity of a contract is to be limited to effect only from now on. Under this view, invalidity of a continuing contract, that is a contract under which a continuous obligation relationship is established between the parties, has ex nunc effect, therefore there is no unwinding of the continuous obligation relationship. This standpoint of Swiss, Austrian, and German law, as well as the various theoretical foundations on which it is based is analysed in the paper. The legal consequences of invalidity of contract under Croatian law are discussed, especially in relation to the obligation of restitution. The paper examines whether it is possible and necessary under Croatian law de lege lata to apply the comparative law doctrine on the limitation of the effect of invalidity of continuing contracts.

Keywords: continuous obligation relationship; continuing contract; invalidity of contract; obligation of restitution.

\section{Zusammenfassung}

\section{RECHTSFOLGEN DER UNGÜLTIGKEIT EINES DAUERHAFTEN VERTRAGS}

Im kroatischen sowie auch im schweizerischen, österreichischen und deutschem Recht hat Vertragsungültigkeit Wirkungen ex tunc. Eine der Rechtsfolgen der Vertragsungültigkeit ist die Restitutionspflicht, die entsteht, wenn eine der Vertragsparteien der anderen Vertragspartei eine Leistung aus dem ungültigen Vertrag

* Ivan Tot, Ph.D., postdoctoral researcher, University of Zagreb, Faculty of Economics, itot@net. efzg.hr. 
erbringt, wobei auf das schuldrechtliche Verhältnis zwischen den Vertragsparteien eines ungültigen Vertrags die Regeln über die Rückgabe des Erlangten ohne rechtlichen Grund, beziehungsweise die Regeln über ungerechtfertigte Bereicherung, angewendet werden. Im schweizerischen, österreichischen und deutschen Recht gilt die Ansicht, dass in dauerhaften Schuldverhältnissen, bei denen die Erfüllung einer dauerhaften Verpflichtung schon zu Stande gekommen ist, die Wirkung der Vertragsungültigkeit ausschließlich für die Zukunft beschränkt wird. Dieser Ansicht nach tritt die Ungültigkeit eines dauerhaften Vertrags, beziehungswiese des Vertrags, durch den ein dauerhaftes Schuldverhältnis gegründet wurde, ex nunc ein, so dass es zur Rückabwicklung des dauerhaften Schuldverhältnisses nicht kommt. Der Beitrag analysiert diese Ansichten des schweizerischen, österreichischen und deutschen Rechts sowie auch die theoretischen Grundlagen, auf denen sie sich stützen. Es werden auch die Rechtsfolgen der Vertragsungültigkeit im kroatischen Recht, insbesondere die Restitutionspflicht, besprochen. Es wird geprüft, ob man auch im Rahmen des kroatischen Rechts die rechtsvergleichende Lösung über die Beschränkung der Ungültigkeit eines dauerhaften Vertrags möglicherweise de lege lata anwenden könnte oder sollte.

Schlüsselwörter:dauerhaftes Schuldverhältnis; dauerhafter Vertrag; Vertragsungültigkeit; Restitutionspflicht.

Riassunto

\section{LE CONSEGUENZE GIURIDICHE DELL'INVALIDITA' DEL CONTRATTO DI DURATA}

L'invalidità del contratto nel diritto croato, come anche nel diritto svizzero, austriaco e tedesco, in via di principio produce effetti ex tunc. Una delle conseguenze giuridiche dell'invalidità del contratto è costituita dall'obbligazione di restituzione che sorge se una delle parti ha adempiuto alla prestazione nei confronti dell'altra parte a soddisfacimento dell'obbligazione che ha fonte nel contratto invalido, allorquando al rapporto obbligatorio tra le parti del contratto invalido si applichino anche le regole della restituzione a seguito di acquisto senza titolo, ossia le regole dell'istituto dell'arricchimento senza causa. Nei diritti svizzero, austriaco e tedesco si rinvengono orientamenti secondo i quali nei rapporti obbligatori di durata nei quali sia iniziato l'adempimento della prestazione di durata sarebbe necessario limitare gli effetti dell'invalidità del contratto, riferendola soltanto al futuro. Secondo tali orientamenti l'invalidità del contatto di durata, o meglio del contratto che è fonte di un rapporto obbligatorio di durata esplica effetti ex nunc. Nel lavoro si disaminano tali orientamenti nei diritti svizzero, austriaco e tedesco, come anche le basi teoriche sulle quali si fondano. Si discute delle conseguenze giuridiche dell'invalidità del contratto nel diritto croato ed in particolare dell'obbligo di restituzione. Si pone 
altresì l'interrogativo se nel quadro normativo croato sia immaginabile ed opportuno de lege lata adottare tali soluzioni comparate circa la possibile limitazione degli effetti dell'invalidità del contratto di durata.

Parole chiave: rapporto obbligatorio di durata; contratto di durata; invalidità del contratto; obbligo di restituzione. 